GEOLOGICAL SURVEY BULLETIN 1108-G
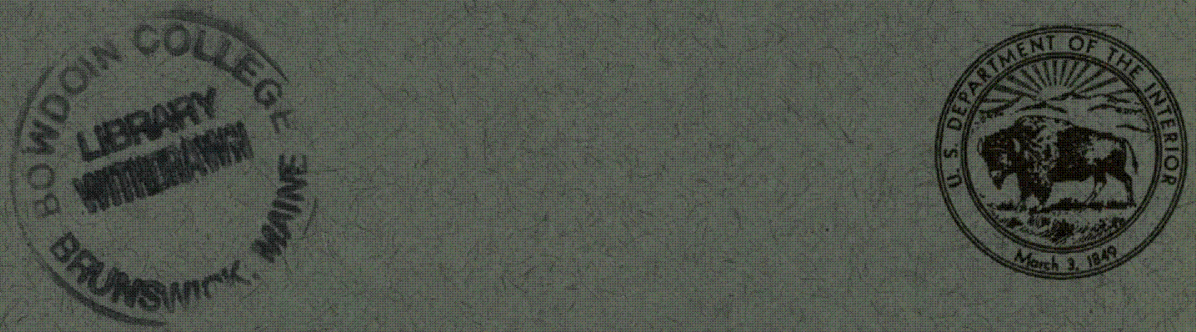



\section{Geology of the}

\section{Freshwater Bay Area}

\section{Chichagof Island, Alaska}

By ROBERT A. LONEY, WILLIAM H. CONDON, and J. THOMAS DUTRO, JR.

\section{MINERAL RESOURCES OF ALASKA}

G E O L O G I AL S U R V E Y B U L L E T I N 1108-C

General geology of an area underlain largely by middle Paleozoic rocks, with emphasis on stratigraphy, structure, and petrography

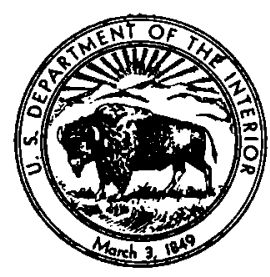




\section{UNITED STATES DEPARTMENT OF THE INTERIOR}

STEWART L. UDALL, Secretary

\section{GEOLOGICAL SURVEY}

Thomas B. Nolan, Director

For sale by the Superintendent of Documents, U.S. Government Printing Office Washington 25, D.C. 


\section{CONTENTS}

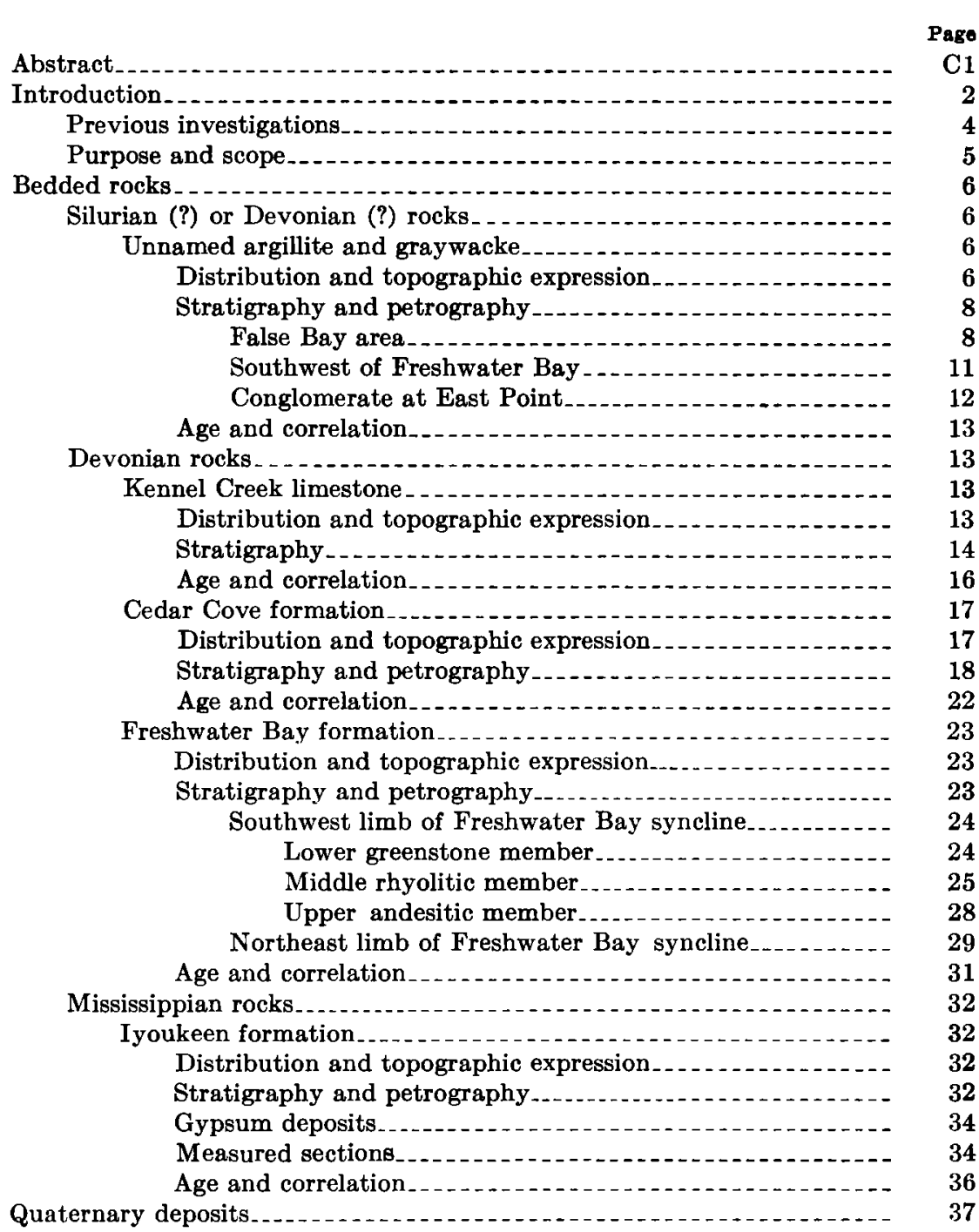


Page

Intrusive igneous rocks

Gypsum Creek quartz monzonite._... 38

Distribution and location.... 38

Petrography

Contact metamorphism

Pluton at the head of Kennel Creek

Contact metamorphism.

Small plutons.

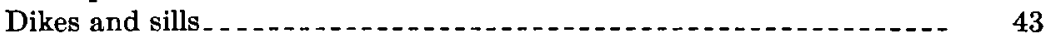

Andesite dikes and sills._._._. 43

Spessartite lamprophyre

Structure._._.

Freshwater Bay syncline

Faults and lineaments._._.

Eastward-striking faults and associated lineaments _._.

Northwestward-striking faults and associated lineaments _ _._. $\quad 46$

Northwestward-striking thrust faults

Marginal thrust faults near intrusive bodies

Geologic history

Literature cited _.

Index

\section{ILLUSTRATIONS}

[Plates in pocket]

Plate 1. Geologic map and sections of the Freshwater Bay area.

2. Correlated composite stratigraphic sections.

Figore 1. Index map of southeastern Alaska.

\section{TABLES}

TaBLw 1. Composite section for the Freshwater Bay area

2. Summary of plutonic igneous bodies in the Freshwater Bay area. 
MINERAL RESOURCES OF ALASKA

\title{
GEOLOGY OF THE FRESHWATER BAY AREA CHICHAGOF ISLAND, ALASKA
}

By Robert A. Loney, William H. Condon, and J. Thomas Dutro, Jr.

\begin{abstract}
The Freshwater Bay area comprises about 140 square miles in the northeastern part of Chichagof Island, southeastern Alaska. A sequence of Paleozoic rocks more than 24,000 feet thick is divided into 5 formations, 4 of which are named for the first time. From the base upward the units are : unnamed argillite and graywacke (Silurian(?) or Devonian(?)), which are more than 5,000 feet thick; Kennel Creek limestone (Middle Devonian), which consists of fossiliferous limestone that averages about 3,500 feet thick; Cedar Cove formation (Middle and Upper(?) Devonian), which consists of graywacke, argillite, conglomerate, and fossiliferous limestone that are about 2,600 feet thick; Freshwater Bay formation (Upper Devonian), which consists of greenstone, rhyolite and andesite flows, pyroclastic rocks, and associated sedimentary rocks that are about 6.500 feet thick ; and Iyoukeen formation (Mississippian), which consists of fossiliferous cherty limestone and shale that are about 4,500 feet thick.

A possible unconformity lies between the unnamed argillite and graywacke and the overlying Kennel Creek limestone. Unconformities occur both at the base and at the top of the Freshwater Bay formation.

Five deep-seated plutonic bodies intrude the Paleozoic sequence. Their age can be determined no closer than post-Late Mississippian and pre-Quaternary. Two of the five plutons are 4 square miles or more in area and are quartz monzonitic to granitic in composition. The remaining 3 are less than 1 mile square and are dioritic to quartz dioritic in composition. The plutons have abrupt borders and narrow contact aureoles. Near the unit here named the quartz monzonite, minor marginal thrust faults in the surrounding country rock are directed away from the intrusive body at high angles.

-At some time after the deposition of the Iyoukeen formation and before the deposition of the Quaternary unconsolidated deposits, the Paleozoic rocks were folded into a major southeastward-plunging syncline. Folding was followed by igneous intrusion and the development of a fault system. A tentative order of events, after the initiation of folding, is: (1) eastward-striking left-lateral faulting; (2) plutonic intrusion accompanied by marginal thrust faulting; (3) northwestward-striking, right-lateral faulting; (4) southwestward-directed thrust faulting.
\end{abstract}




\section{INTRODUCTION}

Freshwater Bay is on the northeastern part of Chichagof Island, one of the larger islands in the northern part of the Alexander Archipelago of southeastern Alaska. (See fig. 1.) The area is accessible

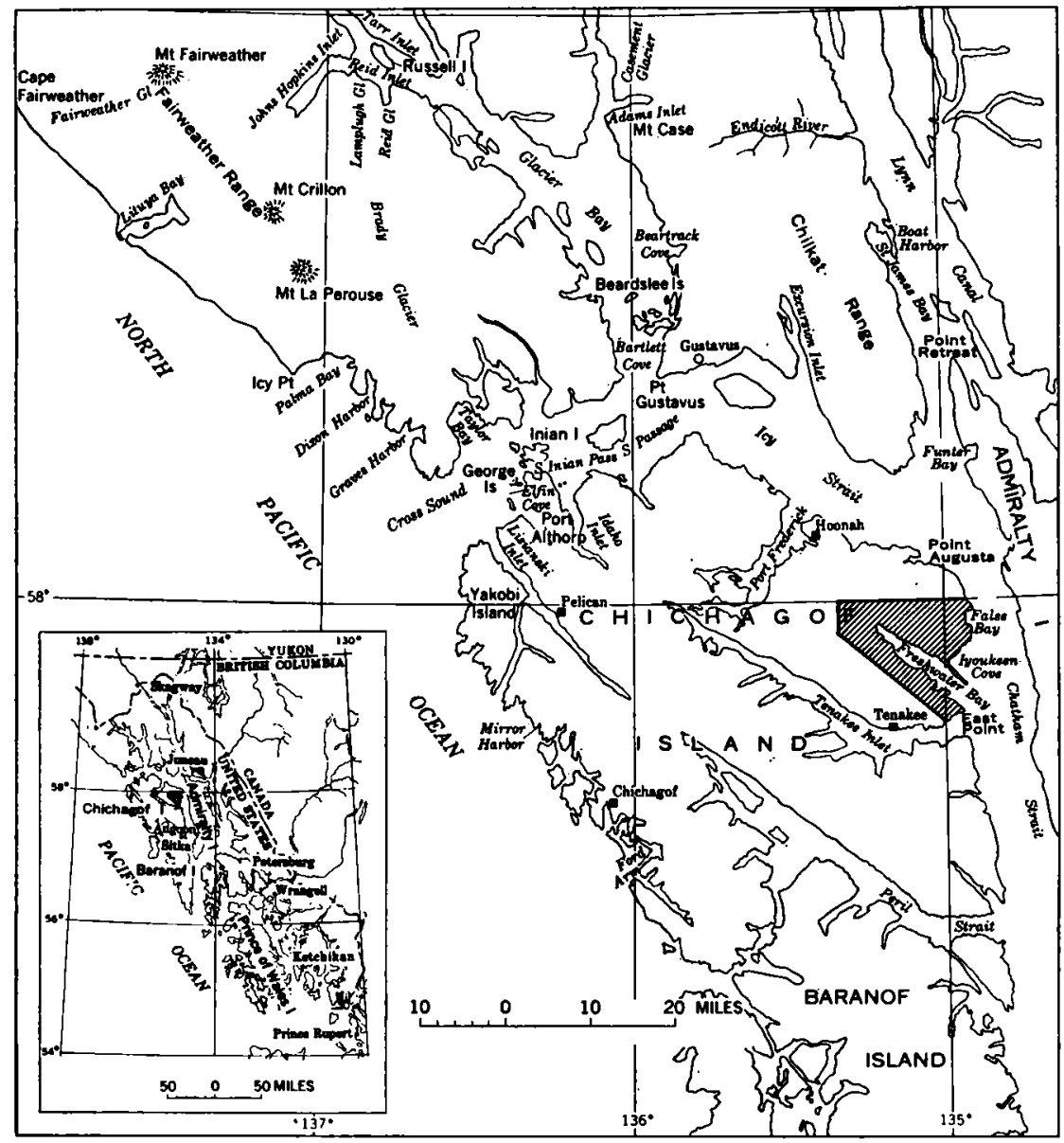

Frodar 1.- Index map of southeastern Alaska showing location of Freshwater Bay area, Chlchagof Island, Alaska.

by boat or aircraft only; no roads exist. The nearest settlement, Tenakee, is a fishing village about 8 airline miles southwest of Pavlof Harbor, a small sheltered anchorage on the south shore of Freshwater Bay.

The area mapped encompasses about 140 square miles and includes the western quarter of the Sitka D-3 quadrangle north of Tenakee 
Inlet and the northern two-thirds of the Sitka D-4 quadrangle. The southwestern limit of mapping extends from a point on Tenakee Inlet about 2 miles southwest of East Point northwest to a point about 8 miles south of the northwest corner of the Sitka D-4 quadrangle. About one-sixth of the Freshwater Bay area as defined is covered by water.

Major topographic features show a strong northwestward orientation, which is a direct expression of the structure of the underlying rocks. Most prominent of these features is Freshwater Bay, which extends from Chatham Strait northwestward for about 13 miles. Although about $21 / 2$ miles wide at its mouth, this feature tapers to less than half a mile wide at its head. A low broad valley continues the trend of Freshwater Bay northwestward to the western border of the map.

Freshwater Bay is surrounded by mountainous terrain, composed chiefly of long rounded northwestward-trending ridges with some shorter transverse northeastward-trending ridges. The ridges average about 2,000 feet in altitude with several peaks reaching above 3,000 feet. The highest point in the area, with an altitude of 3,395 feet, is on the first ridge north of the head of the bay. Here also is the maximum relief, because the southern slope of the ridge rises directly from sea level.

Stream valleys are generally narrow with the exception of the broad valley at the head of Freshwater Bay, in which the North Fork of Freshwater Creek flows, and the valley of Iyouktug Creek near the northeast corner of the map area. All the major valleys are U-shaped, indicating former valley glaciation, and the valleys of Pavlof River, Kennel Creek, and Seal Creek, entering Freshwater Bay, appear to be hanging about 100 feet above sea level.

Freshwater Bay, along with southeastern Alaska in general, has a mild climate and abundant precipitation. Because no weather stations are located either within the area or in adjacent northeastern Chichagof Island, the climatic summary below is taken from U.S. Weather Bureau data recorded at Angoon, Admiralty Island, about 30 airline miles to the southeast, and at Juneau, about 35 airline miles to the northeast. Although these stations lie outside the immediate vicinity of the Freshwater Bay area, both are at sea level and in general the data from them indicate the climate to be expected within the region.

Precipitation is distributed rather evenly throughout the year with September, October, and November receiving the greatest amount and May, June, and July receiving the least. 
Average precipitation, in inches, for the years 1931-55

\begin{tabular}{|c|c|c|c|c|c|c|c|c|c|c|c|c|c|}
\hline Station & Jan. & Feb. & Mar. & Apr. & May & June & July & Aug. & Sept. & Oct. & Nov. & Dec. & $\begin{array}{l}\text { An } \\
\text { nual }\end{array}$ \\
\hline $\begin{array}{l}\text { Juneau } \\
\text { Angoon. }\end{array}$ & $\begin{array}{l}7.18 \\
4.81\end{array}$ & $\begin{array}{l}\text { 5. } 63 \\
\text { 3. } 95\end{array}$ & $\begin{array}{l}5.41 \\
2.88\end{array}$ & $\begin{array}{l}5.46 \\
2.92\end{array}$ & $\begin{array}{l}5.22 \\
2.52\end{array}$ & $\begin{array}{l}3.95 \\
2.10\end{array}$ & $\begin{array}{l}5.03 \\
3.25\end{array}$ & $\begin{array}{l}7.33 \\
2.96\end{array}$ & $\begin{array}{r}\text { 10. } 15 \\
6.29\end{array}$ & $\begin{array}{r}11.18 \\
7.42\end{array}$ & $\begin{array}{l}\text { 9. } 10 \\
\text { 5. } 66\end{array}$ & $\begin{array}{l}7.61 \\
4.82\end{array}$ & $\begin{array}{l}83.25 \\
60.68\end{array}$ \\
\hline
\end{tabular}

Summers are cool and winters mild for this latitude as indicated by the summary as follows:

Temperature summary, in degrees Fahrenheit, for the years 1931-55

\begin{tabular}{r|r|r|r|r|r}
\hline Station & $\begin{array}{r}\text { January } \\
\text { average }\end{array}$ & $\begin{array}{r}\text { July } \\
\text { average }\end{array}$ & $\begin{array}{c}\text { Absolute } \\
\text { maximum }\end{array}$ & $\begin{array}{c}\text { Absolute } \\
\text { minimum }\end{array}$ & \multicolumn{1}{c}{$\begin{array}{c}\text { Annual } \\
\text { mean }\end{array}$} \\
\hline Juneau & & & & \\
Angoon & 27.5 & 56.6 & 89 & -15 & 42.2 \\
\hline
\end{tabular}

The Freshwater Bay area is heavily forested except for the tops of the higher ridges. Western hemlock and Sitka spruce dominated the dense vegetation below timberline, which ranges from 1,500 to 2,000 feet in altitude. Above timberline, lichens, sedges, mosses, and scattered shrubs replace the taller vegetation of the lower altitudes.

\section{PREVIOUS INVESTIGATIONS}

Most of the contributions to the geology of the Freshwater Bay area were published before 1912. Since that time, and until the present work was undertaken, field investigations have been confined largely to the gypsum deposits at Iyoukeen Cove.

Prior to 1912 , C. W. and F. E. Wright made extensive reconnaissance explorations in southeastern Alaska. Results of these investigations, published in Brooks and others (1906, 1907, and 1908), contain reconnaissance geologic maps of southeastern Alaska including the shorelines of the Freshwater Bay area. The reports, mostly by C. W. Wright, deal largely with the gypsum deposits at Iyoukeen Cove but also contain comments on the geology of the rocks adjacent to the deposits.

The first definitive work on the rocks of the Freshwater Bay area (Kindle, 1907, p. 314-337) presents lists of fossils collected from strata at Freshwater Bay together with brief lithologic descriptions and age correlation. The paper was based on a reconnaissance of the area by Kindle and C. W. Wright in the summer of 1905 .

Knopf reported briefly on the rocks along the north coast of Chichagof Island (1912, p. 11, 12). 
As a result of fieldwork in 1917, Kirk (1918, p. 511-515) listed a conglomerate at Freshwater Bay among those of southeastern Alaska regarded by him as example of possible Paleozoic tillite. The conglomerate in the Cedar Cove formation (of this report) northwest of Kennel Creek on the southwest shore of Freshwater Bay may be the one to which he referred.

In addition, Kirk (1927a, 1927b) reported a new pelecypod genus, collected from the thick limestone (described on p. C13-C17) exposed on the southwest shore of Freshwater Bay. The limestone is named herein the Kennel Creek limestone.

Buddington and Chapin (1929, p. 80, 84, 94, 108, 110, 315) included the Freshwater Bay area in their summary of the geology of Southeastern Alaska, but the information is based largely upon the investigations, both published and unpublished, of the earlier workers mentioned above. The major northwestward-trending syncline, whose axis parallels Gypsum Creek northeast of Freshwater Bay, was called the "Freshwater Bay syncline" by Buddington and Chapin (1929, p. 315).

B. D. Stewart examined the gypsum deposits at Iyoukeen Cove in 1928 and reported briefly on the status of the mines there (in Smith 1932, p. 173-177).

Finally, the investigation of the gypsum deposits at Iyoukeen Cove, by Flint and Cobb (1953) in 1946, was confined to the area immediately adjacent to the gypsum deposits.

\section{PURPOSE AND SCOPE}

The present work was undertaken in order to provide detailed stratigraphic and structural information as an aid to the reconnaissance mapping of southeastern Alaska.

The Freshwater Bay area was selected for study because it contains one of the most complete and relatively undisturbed stratigraphic sections in southeastern Alaska. The areal distribution, stratigraphy, and petrography of the rock units, together with their structural relations, were studied in sufficient detail to present a coherent picture of the geology. Unconsolidated surficial deposits were not studied in detail.

All field mapping was done at a scale of $1: 63,360$, on U.S. Geological Survey topographic quadrangles Sitka (D-3) and Sitka (D-4), with the aid of $1: 40,000$-scale vertical aerial photographs. Geologic contacts were extended and refined in the office by stereoscopic examination of the aerial photographs. 
In June 1956, J. Thomas Dutro, Jr., W. H. Condon, and Robert A. Loney spent a total of 21 days mapping the shore outcrops and making fossil collections.

From June 21 to August 4, 1957, the country inland from the shore was mapped by Robert A. Loney and W. H. Condon. Transportation into the interior was facilitated by the use of a helicopter based on the Geological Survey motor vessel Stephen R. Capps. The helicopter carried field parties to and from the high country above timberline, where traverses were made on foot.

In general, the grade scale of Wentworth (1922, p. 377-392) was used in the description of the grain size of fragmental sedimentary rocks, and the terminology of Wentworth and Williams (1932, p. 19-53) was used for pyroclastic rocks.

Thin sections of representative rock types were studied by standard microscopic methods. In addition, cut rock surfaces were stained, using the sodium cobaltinitrite method, to determine the amount of potassic feldspar. Plagioclase composition was determined, where possible, by the refractive index of crushed fragments in high-dispersion oils, using the method of Emmons and Gates (1948, p. 612618). In addition, the copper nitrate stain method (Rodgers, 1940, p. 787-798) was used to distinguish between calcite and dolomite. $\mathrm{X}$-ray defraction methods were used to determine the mineral composition of a few specimens, when microscopic methods produced indecisive results. The X-ray data were interpreted by Julius Schlocker of the U.S. Geological Survey. When there was a need to supplement optical data, specific gravities were determined by means of a Berman balance.

Ernest H. Lathram, Henry C. Berg, and Maurice Grolier of the U.S. Geological Survey provided data on the stratigraphy and distribution of rocks along the northern and western boundaries of the map area.

\section{BEDDED ROCKS}

Bedded rocks ranging in age from Silurian (?) to Late Mississippian are folded into a southeastward-plunging syncline, the Freshwater Bay syncline, which underlies the entire map area. The composite section ranges in thickness approximately from 18,500 to more than 24,000 feet (table 1 ).

\section{SILURIAN( $($ ) OR DEVONIAN(?) ROCKS \\ UNNAMGD ARGILLITE AND GRAYWACKE DISTRIBUTION AND TOPOGRAPHIC EXPRESSION}

$\Lambda$ medium- to thin-bedded argillite, graywacke, and slate sequence crops out along the west and north shores of False Bay and northward 
along Chatham Strait at the northeast corner of the map area. These rocks form a continuous belt, about 1 to 2 miles wide, that stretches along the northeast coast of Chichagof Island from Chatham Strait northwestward to the entrance of Port Frederick, a distance of about 22 miles.

The argillite and graywacke sequence underlies an area of diverse topography including low, broad valleys and, locally, high ridges. The lowlands are underlain largely by argillite, whereas the ridges are composed of interbedded graywacke and argillite.

Argillite, graywacke, and conglomerate form discontinuous exposures along the southwest border of the map area. These rocks, tentatively correlated with the clastic sequence at False Bay, are poorly known owing to lack of exposures and structural complexity resulting from the emplacement of the large pluton in the drainage area of Pavlof River and Kennel Creek.

TABLE 1.-Composite section for the Freshwater Bay area, Chichagof Island, Alaska

\begin{tabular}{|c|c|c|c|c|}
\hline System or serles & \multicolumn{2}{|c|}{ Formation and member } & Description & $\begin{array}{c}\text { Thicknes. } \\
\text { (feet) }\end{array}$ \\
\hline Quaternary & \multicolumn{2}{|c|}{$\begin{array}{c}\text { Unnamed } \\
\text { Unconformity }\end{array}$} & $\begin{array}{l}\text { Unconsolidated alluvial, glacial, } \\
\text { and colluvial deposits; chiefly } \\
\text { gravel, sand, silt, and talus } \\
\text { debris. }\end{array}$ & \\
\hline $\begin{array}{c}\text { Upper } \\
\text { Mississippian }\end{array}$ & \multirow{3}{*}{ 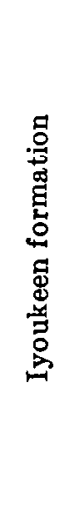 } & $\begin{array}{l}\text { Upper } \\
\text { limestone } \\
\text { member }\end{array}$ & $\begin{array}{l}\text { Limestone, dominantly dark- } \\
\text { gray, thin to thick-bedded; } \\
\text { contains dark-gray nodular } \\
\text { chert lenses; lithostrotionoid } \\
\text { corals, solitary corals, and } \\
\text { brachiopods common; top is } \\
\text { erosional surface. }\end{array}$ & $\begin{array}{r}2,000- \\
3,500-\end{array}$ \\
\hline \multirow{2}{*}{$\begin{array}{c}\text { Lower } \\
\text { Mississippian }\end{array}$} & & $\begin{array}{l}\text { Middle } \\
\text { member }\end{array}$ & $\begin{array}{l}\text { Shale, dark-gray, noncalcareous } \\
\text { to calcareous; grades into } \\
\text { dark-gray yellow-weathering } \\
\text { shaly limestone to northwest; } \\
\text { contains brachiopods, corals. }\end{array}$ & $\begin{array}{r}500- \\
750\end{array}$ \\
\hline & & $\begin{array}{l}\text { Lower } \\
\text { limestone } \\
\text { member }\end{array}$ & $\begin{array}{l}\text { Limestone, dark-gray, thin- to } \\
\text { medium-bedded; sparse dark- } \\
\text { gray chert beds; contains } \\
\text { brachiopods and corals. }\end{array}$ & $\stackrel{200-}{600}$ \\
\hline $\begin{array}{c}\text { Upper } \\
\text { Devonian }\end{array}$ & \multicolumn{2}{|c|}{ Unconformity } & $\begin{array}{l}\text { Volcanic and sedimentary rocks } \\
\text { consisting of greenstone, } \\
\text { rhyolite, and andesite flows, } \\
\text { tuff, and breccia; minor } \\
\text { amounts of graywacke, argil- } \\
\text { lite, and limestone; brachio- } \\
\text { pod faunule in upper part, } \\
\text { northwest of map area at } \\
\text { Port Frederick. }\end{array}$ & $\begin{array}{r}5,000 \\
6,500\end{array}$ \\
\hline
\end{tabular}


TABLE 1.-Composite section for the Freshwater Bay area, Chichagof Island, Alaska-Continued

\begin{tabular}{|c|c|c|c|c|}
\hline System or series & Form & lon and member & Description & $\begin{array}{c}\text { Thickness } \\
\text { (feet) }\end{array}$ \\
\hline \multirow[t]{2}{*}{$\begin{array}{c}\text { Middle and } \\
\text { Upper(?) } \\
\text { Devonian }\end{array}$} & \multirow{2}{*}{ 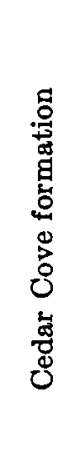 } & $\begin{array}{l}\text { Upper } \\
\text { member }\end{array}$ & $\begin{array}{l}\text { Limestone, tuff, and dolomite } \\
\text { interbedded; limestone is dark } \\
\text { gray, thin bedded, fossilifer- } \\
\text { ous in upper part and light } \\
\text { gray, massive, unfossiliferous } \\
\text { at base; dolomite is medium } \\
\text { gray and sugary textured; } \\
\text { tuff is yellow weathering and } \\
\text { siliceous. }\end{array}$ & $1,10-$ \\
\hline & & $\begin{array}{l}\text { Lower } \\
\text { member }\end{array}$ & $\begin{array}{l}\text { Graywacke, argillite, limestone, } \\
\text { and conglomerate interbedded; } \\
\text { member varies in thickness and } \\
\text { is nonfossiliferous; transitional } \\
\text { with underlying Kennel } \\
\text { Creek limestone. }\end{array}$ & 1,500 \\
\hline $\begin{array}{c}\text { Middle } \\
\text { Devonian }\end{array}$ & \multicolumn{2}{|c|}{$\begin{array}{l}\text { Kennel Creek } \\
\text { limestone }\end{array}$} & $\begin{array}{l}\text { Limestone, dark- and light-gray, } \\
\text { fossiliferous; thick bedded near } \\
\text { base and thin bedded near } \\
\text { top; Amphipora and Pycino- } \\
\text { desma in middle half. }\end{array}$ & $\begin{array}{r}2,200- \\
5,000\end{array}$ \\
\hline $\begin{array}{c}\text { Devonian(?) } \\
\text { or Silurian(?) }\end{array}$ & \multicolumn{2}{|c|}{ Unnamed } & $\begin{array}{l}\text { Argillite, graywacke, and a minor } \\
\text { amount of conglomerate, in } \\
\text { part calcareous; dominantly } \\
\text { medium to thin bedded; un- } \\
\text { fossiliferous; base not exposed. }\end{array}$ & $5,000+$ \\
\hline
\end{tabular}

GTRATIGRAPHY AND PETROGRAPHY

FALSE BAY AREA

Stratigraphically, the argillite and gray wacke at False Bay appears to be the oldest rock unit in the map area. No base is exposed within the area or to the north and west along the northeast coast of Chichagof Island. Structural complexity on the west shore of False Bay and lack of exposures inland obscure the stratigraphic relations between the dominantly graywacke sequence north of Iyouktug Creek and the dominantly argillite sequence south of the creek. Similarly, the relation between the argillite and the Kennel Creek limestone on the south shore of False Bay is not clear. The argillite-graywacke beds along the west shore of False Bay have been subjected to smallscale folding and faulting, making accurate measurement of stratigraphic thickness difficult. Thickness estimates of the graywacke and argillite unit range from 5,000 feet to 6,000 feet, depending upon structural interpretation. These must be considered minimum thicknesses because only the upper part of the formation is exposed in the Freshwater Bay area. 
The dominantly graywacke sequence at False Bay consists of more than 3,500 feet of alternate beds of dark-greenish-gray and mediumlight-gray thin-bedded chloritic to calcareous fine- to medium-grained arkosic graywacke and grayish-black well-indurated slightly calcareous argillite or slate. Beds range from 0.1 to 1 foot in thickness; the graywacke beds are usually 2 or 3 times as thick as the argillite beds. Slate is common but is generally confined to local areas of intense folding; most of the fine-grained well-indurated argillaceous rock lacks cleavage or any other regular structure and is called here argillite.

The graywacke displays graded bedding, convolute bedding, smallscale crossbedding, flute casts, and drag marks. Each graywacke bed grades upward from coarser to finer grain size and, imperceptibly, into the argillite bed above. Small-scale crossbedding sets range from 0.5 to 1 inch thick. Convolute bedding, as defined by Kuenen (1953, p. 1056-1058), is apparently confined to the upper finer grained part of each graywacke bed. Bed sole markings, similar to those called flute casts and drag marks by Kuenen (1957, p. 235-246), were observed in several places.

Alternate medium-light-gray calcareous and dark-greenish-gray chloritic layers are characteristic of the graywacke. Although these layers are roughly parallel to the bedding, several sets of alternate light-colored and dark layers may occur within a single graded cycle. The light-colored layers are generally predominant.

The graywacke is fine grained, for the most part, and the grain size ranges from 0.0625 to $0.4 \mathrm{~mm}$. The median falls in the range 0.0625 to $0.125 \mathrm{~mm}$ (very fine sand size). Sorting is poor; coarser grains are suspended in a finer matrix and rarely touch one another.

Component percentages in the dark chloritic layers, based on visual estimates in thin section, are: quartz, 50 percent; plagioclase $\left(\mathbf{A n}_{5}\right.$ and $A_{15-35}$ ) , 20 percent; biotite, 1 percent; and matrix (chlorite, iron ore minerals, clay minerals) 29 percent. The grains in the dark layers range from angular to subangular.

Similar estimates in the light-colored calcareous layers are: quartz, 35 percent; plagioclase $\left(\mathrm{An}_{5}\right), 6$ percent; biotite, 2 percent; rock fragments (chloritic volcanic rock, quartzite, argillite, diorite), 2 percent; and matrix (calcite and minor chlorite, quartz, clay minerals), 55 percent. The grains of quartz and plagioclase are strongly corroded and embayed by the calcite of the matrix.

The greater amount of matrix in the calcareous layers, as compared to the chloritic layers, may be due largely to the solution of quartz and feldspar grains concomitant with the precipitation of calcite. According to Correns $(1950$, p. 51), the precipitation of calcite in 
aqueous solution occurs under alkaline (high $\mathrm{pH}$ ) conditions, whereas silica goes into solution in a similar environment. The frayed quartz and feldspar grains have been observed embedded in calcite matrix only and therefore suggest, in agreement with Correns' conclusions, that conditions favorable for calcite deposition are favorable for silica (and silicate) solution.

The source of the calcite is not known. The calcareous layers parallel but do not coincide with sedimentation units (graded cycles), hence the migration of calcium carbonate-bearing aqueous solutions into the layers is probably postdepositional. In order for the migration to produce widespread uniform layers, the rock or sediment must have had good permeability. If the dark chloritic layers without the calcite represent the normal graywacke, their present lack of permeability suggests that migration of calcium carbonate-bearing solutions occurred before the present stage of lithification.

In most rocks having a grain size in the sand range the darkgreenish-gray chloritic layers contain a poorly sorted assemblage of fragments in which unstable constituents (feldspars) constitute 25 percent or more of the total. The fragments are embedded in matrix composed of chlorite, iron-ore minerals, and clay minerals. The texture and composition of these rocks conform to Pettijohn's (1957, p. 301-314) definition of a graywacke. In addition, owing to the high feldspar content (20 percent or more), rocks of this type may be called high-rank graywacke (Krynine, 1948, p. 147-153) or arkosic graywacke (Gilbert in Williams and others, 1954, p. 291-297).

The predominant calcite-rich matrix of the medium-light-gray layers does not conform to the composition of a typical graywacke according to any of these definitions. Because the rock is considered to be an alteration of the typical graywacke described previously, it may be called a calcareous graywacke to indicate its origin. The texture of the calcareous layers, if the corroded quartz and feldspar grains are restored to their original detrital shape, is identical to that of the typical chloritic graywacke layers. In addition, the calcareous layers exhibit the same sedimentary structures (graded bedding, flute casts, small scale crossbedding, and drag marks) as the typical graywacke.

The predominantly argillite sequence exposed along the west shore of False Bay, south of the mouth of Iyouktug Creek, is composed largely of grayish-black and dark-gray thin-banded calcareous argillite. The black and gray bands range from 0.25 to 1 inch in thickness and apparently represent bedding. The calcareous argillite overlies the gray wacke sequence described previously. Estimates of the thickness of the argillite range from 1,500 to 2,500 feet. 
In general, the argillite and graywacke unit has a uniform appearance over a wide area in northeastern Chichagof Island. The relatively great thickness (more than 5,000 ft) of alternate beds of argillite and graywacke indicates an environment in which deposition varied rhythmically for a considerable length of time. The extensive lateral and vertical development of this environment and the dominant dark gray and green rocks, indicating probable reducing conditions (Pettijohn, 1957, p. 359), suggest deposition in a subsiding marine trough.

Because the argillite lacks structures, which might be interpreted as indicating current action, it probably was deposited below wave base by the settling of fine material in relatively quiet water. The graywacke, on the other hand, characteristically exhibits current-formed structures such as small-scale crossbedding and convolute bedding) and thus must have been deposited in a zone of considerable current action. Both the argillite and graywacke beds are thin and maintain relatively uniform thicknesses across even the largest outcrops. This feature suggests deposition in quiet water. It seems unlikely that the sea bottom was periodically raised into the rough-water zone above wave base for the deposition of each graywacke bed and then lowered below wave base for the deposition of each argillite bed. More probably the graywacke beds represent periodic influxes of coarser material into quiet water below wave base. It is apparent from the abundance of fine matrix in the graywacke that the currents that deposited the graywacke must have been muddy. These muddy currents were too dense and too viscous to allow the separation of the clay-size material from the coarser sizes but were fluid enough to permit graded bedding and current structures to form. Rapid transport from the source area to the place of final deposition is indicated by the presence of unstable mineral types and a lack of grain rounding.

BOUTH WEST OF FRESHW ATER BAT

The sequence of argillite, graywacke, and conglomerate underlying the Kennel Creek limestone southwest of Freshwater Bay, is probably correlative with the argillite and graywacke sequence at False Bay. These clastic rocks crop out in a discontinuous belt southwest of the outcrop belt of the Kennel Creek limestone in the first major ridge southwest of Freshwater Bay. Because the base of the clastic sequence is not exposed in the map area, the true stratigraphic thickness is not known. In addition, structural complexity and lack of good exposures prevent a valid estimate of minimum thickness.

The high country between Kennel Creek and the South Fork of Freshwater Creek contains the best exposures of the clastic sequence. Here the dominant rock type is brownish to light-gray very thin 
bedded highly indurated noncalcareous argillite. Beds range from 0.5 to 2 inches in thickness. The argillite grades imperceptibly into hornblende-biotite hornfels near intrusive igneous contacts.

Conglomerate and pebbly graywacke overlie the argillite and form the upper 100 feet of the clastic sequence. The conglomerate, which directly underlies the Kennel Creek limestone, consists of well-rounded boulders of light-gray leucocratic granite, medium-gxay chert, and medium-dark-gray argillite embedded in a very sparse medium-lightgray noncalcareous argillite matrix. The boulders average 1 foot in greatest dimension. Medium-gray fine- to medium-grained pebbly graywacke, in beds ranging from 2 to 3 feet in thickness, underlies the conglomerate.

\section{CONGLOMERATE AT EAST POINT}

A dark-greenish-gray massive well-indurated pebble-to-cobble conglomerate is exposed along the shore of Tenakee Inlet southwest of East Point. (See sec. 1 of pl. 2.) This conglomerate is composed of rounded pebbles, cobbles, and, in a few places, boulders as much as 6 feet in greatest dimension embedded in a dark-greenish-gray medium-grained graywacke matrix. The average grain size of the coarser fragments is about 2 inches. Fragmental types observed are: dark- and medium-gray fine-grained volcanic rock, light-gray mediumgrained leucocratic granite, dark-gray slate, dark-gray fine-grained graywacke, and dark-gray chert. Igneous rock fragments comprise about 60 percent of the coarse fraction.

The lower contact of the conglomerate is covered by Tenakee Inlet, whereas the upper contact with a massive limestone, tentatively correlater with the Kennel Creek limestone, is well exposed. The contact is irregular and may represent an unconformity, but owing to the lack of observable bedding in both the conglomerate and the limestone no discordance of bedding was observed. Differential compaction of the conglomerate may have caused the irregular upper contact.

Large blocks of limestone, some 6 feet or more in greatest dimension, similar to the overlying limestone, occur in the upper 25 feet of the conglomerate. The conglomerate appears to have flowed plastically around undeformed limestone blocks and therefore indicates that the consolidated limestone blocks were emplaced in unconsolidated gravel. Conglomerate deposited on a rugged limestone terrane might contain such blocks. The present limestone outcrop may represent a topographic high on such a terrane. The conglomerate has a minimum exposed thickness of 500 feet.

The conglomerate at East Point is tentatively correlated with the upper part of the clastic sequence underlying the Kennel Creek limestone in the ridge 2 miles west of the mouth of Kennel Creek, but it 
may represent a conglomeratic lens within the Kennel Creek limestone. In view of the uncertainty of correlation, the conglomerate is shown as a separate unit on plate 1 .

\section{AGE AND CORRELATION}

No fossils have been collected from rocks definitely assigned to this unit within the map area. The rock types are similar to those of a formation mapped along St. James Bay and west and north of Boat Harbor, about 40 to 50 miles north of Point Augusta. North of Boat Harbor, graptolites (Monograptus) in gray-black calcareous slate indicate a Middle or Late Silurian age. The slate from which the graptolites were collected resembles that cropping out at False Bay.

The slate, argillite, graywacke unit appears to lie unconformably beneath the Kennel Creek limestone in the southwestern part of the map area. In the vicinity of Hoonah, about 20 miles west of False Bay, this unit probably lies unconformably below equivalents of the Kennel Creek limestone.

A small collection of fossils was made from one of the limestone boulders near the top of the conglomerate at East Point. Gastropods dominate this small assemblage and have been assigned a Silurian or Devonian age by Ellis Yochelson, who states (written communication, August 1960) :

The collection contains abundant specimens of Coelocaulus. This indicates a mid-Paleozoic age but, after comparisons with available Museum collections and the literature on the genus, it is not possible to indicate a preference for Silurian or Devonian age.

\section{DEVONIAN ROCKS}

\section{KENNEL CRIGHK LDMEGTONE}

The thick fossiliferous limestone sequence typically exposed on the southwest shore of Freshwater Bay both southeast and northwest of the mouth of Kennel Creek is here named the Kennel Creek limestone. It is underlain by the unnamed Silurian( (?) or Devonian( (?) argillite and graywacke sequence and is overlain by the Cedar Cove formation.

\section{DIBTRIBUTION AND TOPOGRAPHIO EXPREBBION}

The Kennel Creek limestone is exposed on both limbs of the Freshwater Bay syncline. Southwest of Freshwater Bay the limestone forms a prominent ridge trending westward from East Point. This ridge loses its identity in a structurally complex area south of Pavlof Harbor, just beyond the map area. The ridge-forming outcrop of the Kennel Creek limestone reappears by faulting at the south end of 
Cedar Cove and extends northwest as a prominent ridge ranging from 1,500 to 3,325 feet in altitude.

North of Freshwater Bay, the Kennel Creek limestone also forms prominent ridges. Sonyakay Ridge, ranging in altitude from 1,500 to 3,000 feet and extending from Chatham Strait northwestward for about 6 miles, consists largely of Kennel Creek limestone. To the northwest the limestone is exposed as a series of prominent peaks on transverse northeastward-trending ridges.

\section{STRATIGRAPHY}

Although the Kennel Creek limestone overlies the Silurian(?) or Devonian (?) argillite and graywacke sequence, the nature of the contact is not known. At the type section near Kennel Creek, the limestone section is terminated at the base by a fault. Complex structure and poor exposures prevented determination of the nature of the lower contact in other areas. The irregular contact between the massive limestone and underlying conglomerate at East Point suggests a disconformity. Because of sparseness of fossils and lack of good exposures in the East Point area, the correlation of the massive limestone with the Kennel Creek limestone and the underlying conglomerate with the Silurian(?) or Devonian(?) clastic sequence is only a tentative one.

The Kennel Creek limestone grades upward into the Cedar Cove formation. The top of the Kennel Creek limestone is arbitrarily drawn at the base of the lowest interbedded limestone and graywacke unit of the Cedar Cove formation. Below this contact, the upper part of the Kennel Creek limestone consists of thin-bedded limestone with very thin siliceous very fine grained tuffaceous partings.

The Kennel Creek limestone ranges from more than 2,200 to 5,000 feet in thickness and averages about 3,500 feet thick. Because the limestone is very massive in some localities, an accurate determination of the structural attitude and effect of faulting could not be made; hence, thickness measurements were not obtained.

Medium- to light-gray medium-grained thick-bedded to massive limestone is a prominent rock type in the lower part of Kennel Creek limestone west and north of the type locality, but is not present at the type locality. The more massive lower part forms large structureless bosslike masses on the ridge crests and peaks. The limestone is nearly homogeneous and grades into white medium- to coarse-crystalline marble near igneous intrusions and in places along the zone of the South Shore fault. The absence of the lower massive sequence at the type locality is probably due to the major fault that cuts off the lower part of the type section. A high cliff composed of white sheared limestone, 
continuous with the outcrop of the lower part of the measured type section southeast of Kennel Creek, may represent, in part, the lower massive part of the Kennel Creek limestone. (See sec. 3, pl. 2.) The lower massive part elsewhere appears to range from 1,000 to 1,500 feet in thickness.

Another kind of rock not represented at the type locality, but present in the lower massive limestone sequence elsewhere, is a pinkishgray sugary-textured medium-crystalline dolomite. The dolomite occurs in beds ranging from 20 to 30 feet in thickness scattered sparsely throughout the lower massive part of the formation. Because the dolomite is less resistent to erosion than the normal limestone, it forms saddles and gulleys in many places. The dolomite has scattered pores ranging from 0.25 to $0.5 \mathrm{~mm}$ in diameter. In contrast, the normal limestone typically has a low porosity. Under the microscope the dolomite appears as intergrowths of subhedral rhombic dolomite crystals with a minor amount of reddish-brown iron-rich material disseminated throughout the thin section. The copper nitrate $\left[\mathrm{Cu}\left(\mathrm{NO}_{3}\right)_{2}\right]$ stain method (Rodgers, 1940, p. 787-798) indicates that there is no calcite present. The amount of insoluble residue obtained by dissolving the dolomite in warm dilute hydrochloric acid was negligible.

The type section of the Kennel Creek limestone is given :

Type section of Kennel Creek limestone along the beach from a point about 0.75 mile southeast of the mouth of Kennel Creek to a point about 0.25 mile northwest of the same creek mouth

Cedar Cove formation :

Lowermost unit:

Thickness

Limestone and graywacke; light- to medium-gray very fine grained to sublithographic limestone interbedded with medium-green fine-grained graywacke; beds 1-2 ft thick; graywacke 20 percent. (See section on Cedar Cove formations.) --

Kennel Creek limestone (incomplete) :

18. Limestone, grayish-black, fine-grained; platy beds generally less than $0.1 \mathrm{ft}$ thick separated by light-greenish-gray siliceous very fine grained tuff laminae: a few yellow-weathering chert beds

17. Limestone and chert; medium-gray fine-grained platy limestone interbedded with thin (0.1 ft) laminae of chert weathering medium gray, light brown or yellow, chert 20-75 percent; outcrop banded in appearance; poorly preserved Amphipora near base.

16. Diabase sill, greenish-gray, medium-crystalline, pyritiferous

15. Limestone, as in unit 14; silicified Amphipora abundant but fewer specimens in upper $20 \mathrm{ft}$ (feet)

60 
Type section of Kennel Creek limestone along the beach from a point about 0.75 miles southeast of the mouth of Kennel Creek to a point about 0.25 mile northwest of the same creek mouth-Continued

Kennel Creek limestone (incomplete)-Continued

Thtoknes: (feet)

14. Limestone, grayish-black, fine-grained; beds $0.3-1$ ft thick; abundant Amphipora and a few Pycinodesma; beds composed largely of Amphipora make up 40 percent of unit; Amphipora silicified to black chert; USGS-5482-SD from upper $5 \mathrm{ft}$.-.-

13. Limestone, grayish-black, flne-grained; bed 0.3-1 ft thick ; common Amphipora and a few Pycinodesma

12. Limestone, dark-gray to grayish-black, very fine to mediumgrained ; even beds $0.3-0.8 \mathrm{ft}$ thick ; upper 100 feet is sublithographic and contains abundant Amphipora and posssible Pycinodesma; USGS-5481-SD from base of upper $100 \mathrm{ft}$

11. Limestone, dark-gray, fine-grained; beds 1-3 ft thick; contains thin chert laminae; abundant silicifled Amphipora

10. Limestone, as in unit 11; beds composed largely of Amphipora make up 30-40 percent of unit; few Pycinodesma; USGS5475-SD from near top of unit

9. Limestone, as in unit 11 ; cobbly-weathering; beds $0.1-0.3 \mathrm{ft}$ thick; Amphipora from upper 5 ft USGS-5491-SD

8. Limestone, as in unit 11; massive beds ; contains Pyoinodesma.-

7. Limestone, as in unit 11 except for upper $50 \mathrm{ft}$., which is composed of cobbly-weathering beds 0.2-0.4 ft. thick; Amphipora abundant and a few speciments of Pycinodesma; 40 percent of beds in upper $50 \mathrm{ft}$. composed largely of Amphipora; USGS-5444-SD from near top of unit.

6. Limestone breccia, dark-gray; angular fragments of dark-gray limestone in medium gray sublithographic limestone matrix--

5. Limestone, dark- to medium-gray, fine- to medium-grained; beds 1-3 ft. thick; cobbly-weathering surfaces

4. Limestone, as in unit 5; Amphipora and Pycinodesma common in top $15 \mathrm{ft}$. USGS-5480-SD.

3. Limestone, grayish-black, fine-grained; beds 0.8-2 ft. thick

2. Limestone, dark-gray, fine-grained, massive; Amphipora near top

1. Limestone, dark-gray, fine-grained; interbedded with light-gray sublithographic limestone; dark beds $0.2-0.5 \mathrm{ft}$. thick; sublithographic beds 1-2 ft. thick; about 40 percent dark-gray limestone; a few breceia beds composed of dark-gray angular limestone fragments in medium-gray limestone matrix.

Fault.

Total exposed thickness Kennel Creek limestone 2,271

\section{AGE AND CORRELATION}

A number of collections were made at the type section of the Kennel Creek limestone on the south side of Freshwater Bay. The fossils from this formation are predominantly of two genera: Amphipora, a small rodlike stromatoporoid, and Pycinodesma, a large pelecypod. Although Pycinodesma, originally described by Kirk (1927a, p. 1-9; 
1927b, p. 543), was considered to be of Late Silurian age, it now seems probable that the stratigraphic significance of this genus was misinterpreted.

The only recorded locality outside Alaska where similar pelecypods have been collected is in the Gold Hill district, Utah. Kirk (in Nolan, 1935, p. 21) reported this occurrence from beds above the Stringocephalus zone, which suggests a late Middle or early Late Devonian age.

Amphipora is extremely common in rocks of Middle and early Late Devonian age throughout the Western United States, Canada, and in other parts of Alaska. This stromatoporoid genus has been reported from the Silurian of Russia, but the faunal evidence supporting this age assignment is either absent or inconclusive.

The stratigraphic evidence that led Kirk to give a Silurian age assignment to the beds at Freshwater Bay has been reevaluated. There now seems to be no compelling argument in favor of a Late Silurian age for these beds, based on physical stratigraphy alone.

The most telling argument for a Middle Devonian age assignment is the occurrence, in beds correlated with the Kennel Creek, of a favositid-rugose coral assemblage that is of probable Middle Devonian age. For this reason the age of the Kennel Creek limestone is here considered to be Middle Devonian.

\section{CHDAR COVE FORMATION}

The sequence of clastic and carbonate rocks overlying the Kennel Creek limestone and underlying the Freshwater Bay formation is here named the Cedar Cove formation. The name is taken from Cedar Cove on the southwest shore of Freshwater Bay, near which the formation is typically exposed. The type section extends from a point on the west shore of Cedar Cove, about due west of the north tip of Cedar Island, northwestward along the shore for a distance of about 3 miles.

\section{DIBTRIBUTION AND TOPOGRAPHIO EXPRESBTON}

The Cedar Cove formation appears to have a restricted distribution in the Freshwater Bay area. The outcrops at Cedar Cove and those northwest of Kennel Creek constitute the best exposures of the formation. Graywacke overlying the massive Kennel Creek limestone at East Point near the mouth of Freshwater Bay is tentatively correlated with the Cedar Cove formation. Whether or not the Cedar Cove formation exists anywhere west of the Kennel Creek fault has not been determined. The formation has not been recognized in the area drained by Freshwater Creek west of the head of Freshwater Bay. Exposures are poor in these areas, however, and it is not certain that the Cedar Cove formation is actually missing. 
Near the north border of the map, near the head of Iyouktug Creek, an estimated 1,250 feet of thin interbeds of argillite, graywacke, and limestone that overlie the Kennel Creek limestone and underlie volcanic rocks of the Freshwater Bay formation are correlated with the Cedar Cove formation. However, poor exposures in this area prevent the obtaining of accurate straigraphic data. Southeast of this locality, along strike, the Cedar Cove formation is missing and the Kennel Creek limestone is in contact with volcanic rocks of the Freshwater Bay formation; exposures on the northwest end of Sonyakay Ridge show this relation clearly. The Cedar Cove formation apparently does not reappear to the southeast between the northwest end of Sonyakay Ridge and Iyoukeen Cove.

Areas underlain by rocks of the Cedar Cove formation in most places consist of lowlands with a few narrow ridges. The conglomerate and the more massive limestone form the ridges.

\section{STRATIGRAPHY AND PETROGRAPHY}

The contact between the Cedar Cove formation and the underlying Kennel Creek limestone appears to be transitional and is arbitrarily drawn at the base of the lowest interbedded graywacke and limestone unit. Below this level the Kennel Creek limestone contains only minor thin beds of fine-grained clastic rocks.

The upper contact of the Cedar Cove formation is not exposed in the Freshwater Bay area; however, this contact is probably an unconformity because the Cedar Cove formation is missing in parts of the area. Where the formation is thinner than normal, thinning appears to be due to the removal of strata from the upper part of the formation. For example, west of Kennel Creek only the lower and nonfossiliferous limestone unit of the upper member remains. West of East Point only the predominantly clastic lower member is present Near the north border of the area, in the headwaters of Iyouktug Creek, the upper member is apparently missing.

The unconformity at the top of the Cedar Cove is further documented by section 4, 5, and 6 shown on plate 2. In these sections, sedimentary rocks occur in the Freshwater Bay formation about 2,500 to 3,000 feet stratigraphically below the top. The sedimentary rock units maintain this level in the three sections, whereas the base of the Freshwater Bay formation appears to rise where the Cedar Cove formation is thick and to fall where the Cedar Cove is thin or nonexistent. This relation suggests deposition of the chiefly volcanic rocks of the Freshwater Bay formation upon an irregular topography cut in the rocks of the Cedar Cove formation.

The Cedar Cove formation, at its type section, may be divided into two members: a lower dominantly thin-bedded argillito member 
and an upper dominantly limestone member. In addition to argillite, the lower member contains thin beds of limestone near the base. The upper member contains a prominent massive unfossiliferous limestone at the base. Overlying the massive limestone is a sequence of thinbedded fossiliferous limestone containing a minor number of thin yellow-weathering siliceous tuff beds. The formation has a maximum exposed thickness of about 2,660 feet at the type section. West of Kennel Creek the lower member contains abundant graywacke and lesser amounts of conglomerate; at this locality the upper fossiliferous part of the upper member is missing. (See measured section p. C21.)

Dark-greenish-gray well-indurated medium- to coarse-grained arkosic lithic graywacke is an important rock type in the lower member northwest of the mouth of Kennel Creek. In hand specimen, the graywacke contains pink coarse (1-3 $\mathrm{mm}$ in diameter) rounded grains scattered throughout and very thin black layers, parallel to bedding, that have a sharply defined base but grade upward into the normal green graywacke. These black layers are composed of rounded pyrite grains and each may represent the beginning of a cycle of graded sedimentation within a single homogeneous-appearing graywacke bed. Aside from the black layers, any given graywacke bed shows few indications of graded bedding, except near the top where grain-size decreases rapidly and medium-grained graywacke grades into an overlying argillite bed within a space of 5 to $10 \mathrm{~mm}$.

In thin section the graywacke appears to be composed of rounded to subrounded grains of plagioclase, potassic feldspar, quartz, and pyrite, with volcanic rock fragments embedded in an abundant matrix composed of chlorite, epidote, secondary albite, secondary quartz, and iron-ore minerals. The pink grains observed in hand specimen appear to be mostly potassic feldspar, but some may be chert. The types of volcanic rock fragments are: porphyritic, composed of plagioclase phenocrysts in a very fine grained chloritic matrix ; silicified, composed of fine and very fine grained mosaics of quartz with minor plagioclase crystals; and partly silicified, with fine trachytic texture, composed of plagioclase microlites, chlorite, and quartz. Detrital grains range from 0.25 to $3 \mathrm{~mm}$. Visual estimates of the component percentages are: plagioclase $\left(\mathrm{An}_{10-15}\right.$ and $\left.\mathrm{An}_{32}\right), 30$ percent; potassic feldspar, 2 percent; quartz, 5 percent; pyrite, 3 percent; volcanic rock fragments, 30 percent; and matrix, 30 percent.

The predominance of unstable components (feldspars and rock fragments constituting more than 60 percent of the rock) embedded in an abundant chloritic matrix agrees with Pettijohn's (1957, p. 301-314) definition of a graywacke. The high percentage of feldspar (greater 
than 30 percent) places this rock among Krynine's (1948, p. 147-153) high-rank graywacke. The high feldspar content and the high percentage of unstable rock fragments (30 percent) classifies this rock as either volcanic graywacke or as arkosic lithic graywacke according to Gilbert (in Williams and others 1954, p. 291-294).

The type section of the Cedar Cove formation is given:

Type section of the Cedar Cove formation from the midale of the southwest shore of Cedar Cove north and west along south shore of Freshwater Bay to a point south of west end of West Redcliff Island

Waterline, low tide:

Cedar Cove formation (incomplete) :

Upper member (incomplete) :

11. Dolomite, medium-gray, sugary, and a few beds of greenish-yellow fine siliceous tuff; beds average $1 \mathrm{ft}$ thick.

Thickness

(feet)

10. Limestone and dolomite; dark-gray fine-grained limestone interbedded with medium-gray fine-grained dolomite; contains a few yellowish-green finegrained tuff laminae; beds $0.5-1$ ft thick

$35+$

9. Limestone, dark-gray to grayish-black, flne-grained; beds $0.1-0.7 \mathrm{ft}$ thick USGS-5489-5D

92

51

8. Limestone and dolomite; dark-gray fine- to mediumgrained limestone interbedded with light-mediumgray yellowish-brown-weathering very fine grained dolomite in beds $0.1-3 \mathrm{ft}$ thick ; corals abundant $20-27$ ft above base of unit USGS-5446-SD

7. Limestone; interbedded light-medium-gray very fine grained and medium-dark-gray medium-grained limestone in beds 0.1-1 ft thick; stromatoporoids 12$16 \mathrm{ft}$ above base ; favositid, thamnoporoid, and cladoporoid corals in lower $12 \mathrm{ft}$ USGS 5483-SD

6. Covered; scattered outcrops along strike indicate unit mostly limestone, as in unit 7 , probably including a 40-45 ft sequence of light-brown very fine grained massive to crossbedded orthoquartzite, near top of interval

5. Marble, white coarse-crystalline, fractured; reddishbrown iron-rich carbonate veins; cut by altered mafic dikes

Total exposed thickness of upper member

Lower member :

4. Argillite, interbedded dark- and light-gray; beds $0.25-0.5$ in. thick; dark beds thicker and discontinuous; cut by porphyritic maflc dike.

3. Covered; stratigraphic thickness questionable owing to probably folding 
Type section of the Cedar Cove formation from middle of the southwest shore of Cedar Cove north and west along south shore of Freshwater Bay to a point south of west end of West Redcliff Island-Continued

Waterline, low tide-Continued

Cedar Cove formation (incomplete)-Continued

Lower member-Continued

Thickness

2. Argillite and limestone; medium-gray siliceous argillite interbedded with light-gray very fine grained limestone; beds $0.5-1$ in. thick; cut by dark-greenishgray altered mafic dikes and sills.

1. Argillite, medium-light-gray and greenish-gray, slightly calcareous; thinly interbedded in beds $0.5-1$ in. thick ; cut by dark-greenish-gray altered mafic dikes and sills

Total thickness of lower member $1,500 \pm$

Total exposed thickness of the Cedar Cove formation $\overline{2,660+}$ Kennel Creek limestone:

Marble, white, massive, stylolitic.

To the west of the type locality a less complete section was measured along the southwest shore of Freshwater Bay.

Section along beach in outcrops extending from 0.25 to 0.6 mile northwest of mouth of Kennel Creek

Covered, probable fault.

Cedar Cove formation (incomplete) :

Upper member:

Thickness (feet)

20. Limestone, medium-gray, fine-grained, massive; contains sparse nodules and stringers of light-gray chert_........-. $40+$

19. Covered 190

Total measured thickness of upper member $230+$

Lower member :

18. Conglomerate and graywacke; medium-gray pebble and cobble conglomerate interbedded with dark-gray medium- to coarsegrained crossbedded pebbiy graywacke; beds 1-15 ft. thick; fragments in conglomerate include dark-gray fine-grained basalt, porphyritic basalt, light-gray leucocratic granite and quartz; matrix is medium-grained graywacke

17. Covered; graywacke blocks in covered interval-_..-....-.- 40

16. Graywacke and limestone; dark-greenish fine- to mediumgrained graywacke interbedded with medium-gray finegrained limestone; beds $0.5-1 \mathrm{ft}$. thick; 20 percent limestone_

15. Graywacke, dark-green, medium-grained, graded bedding; beds $0.1-5 \mathrm{ft}$. thick

14. Graywacke, dark-green, medium-grained; interbedded with thin yellow argillite laminae; beds $0.5-2 \mathrm{ft}$. thick 
Section lalong beach in outcrops extending from 0.25 to 0.6 mile northwest of mouth of Kennel Creek-Continued

Cedar Cove formation (incomplete)-Continued

Lower member-Continued

Thickness

13. Limestone, grayish-black, fine-grained; interbedded with thin siliceous laminae; limestone beds $0.5-2 \mathrm{ft}$. thick

12. Graywacke, red, ferruginous, medium-grained ; platy beds $0.1-$ $0.5 \mathrm{ft}$ thick._._-_._-

11. Greenstone, dark-green, medium-crystalline, amygdaloidal ; calcite amygdales_-_-_-_-_-_-_-_._.

10. Graywacke or tuff, dark-green, medium-grained; beds 3-5 ft. thick (feet)

9. Covered

8. Limestone, grayish-black, fine-grained, massive, nodular ; irregular siliceous argillite beds around nodular limestone masses

7. Limestone and graywacke, grayish-black, coarse- and finegrained ; interbedded with dark-green medium-grained graywacke; limestone beds 0.8-1.5 ft. thick; graywacke composes 30 percent of beds

6. Argillite and graywacke ; greenish-yellow argillite interbedded with green fine-grained graywacke; beds of graywacke $0.5-$ 2 ft. thick ; argillite $0.8-1.5$ ft. thick

5. Graywacke, dark-green, medium-grained; contains a few pebble layers; beds 1-2 ft. thick

4. Graywacke and argillite as in unit 6._. 10

3. Graywacke as in unit 5

2. Covered -..-_-_-_-_-_-_-_-_-_-_-_-_-_-_-_-_-_-_-- 95

1. Limestone and graywacke; light- to medium-gray very fine grained to sublithographic limestone interbedded with medium green fine-grained graywacke; beds 1-2 ft. thick; graywacke 20 percent

Total measured thickness of lower member

Total measured thickness of Cedar Cove formation 880

\section{AGE AID CORRELATION}

Limestone beds assigned to the upper part of this unit are very fossiliferous. A wide variety of rugose corals, tabulate corals, and stromatoporoids have been collected at several localities in and near the type section.

As defined in this report, the Cedar Cove formation contains several rock types. In the section north of Kennel Creek the lower part is dominated by graywacke and conglomerate. Graywacke and limestone beds occur both above and below the conglomerate in this section. Along the south side of Freshwater Bay the clastic phase is represented by a quartzite. The coral-bearing beds lie above the clastic rock in this sequence. 
The fossils are of types found elsewhere in the world in beds of similar facies that range in age from late Middle to early Late Devonian. Clastic layers within the overlying Freshwater Bay formation at Port Frederick contain fossils of late Frasnian age, giving an effective upper limit for the age of the Cedar Cove. For purposes of this report, this formation is considered of Middle and Upper(?) Devonian age, since it could be possibly as young as early Late Devonian (early Frasnian).

\section{FRESHW ATER BAY FORMATION}

The thick sequence of volcanic and intercalated sedimentary rocks overlying the Cedar Cove formation and, in places, the Kennel Creek limestone and underlying the Iyoukeen formation is here named the Freshwater Bay formation.

The type locality is near the head of Freshwater Bay; here shoreline exposures contain rock types which are considered characteristic of the formation.

\section{DISTRIBUTION AND TOPOGRAPHIO EXPREBSION}

The rocks of the Freshwater Bay formation form a northwestwardtreading belt of exposures averaging about 2 miles wide at Freshwater Bay, on the southwest limb of the Freshwater Bay syncline. The outcrop belt widens to more than 3 miles to the northwest near the west margin of the map area. On the northeast limb of the syncline, the outcrop belt maintains a width of about 1 mile from the headwaters of Wukuklook Creek northwestward.

For the most part, the rocks of Freshwater Bay formation are nonresistant and underlie valleys and low ridges. Freshwater Bay and the broad valley continue to trend northwestward and are largely underlain by the volcanic rock of this formation.

\section{STRATIGRAPHY AND PETROGRAPHY}

Both the upper and the lower contacts of the Freshwater Bay formation appear to represent unconformities. The evidence for the lower unconformity is largely stratigraphic. Different beds underlie the Freshwater Bay formation in different places. The Codar Cove formation is the underlying formation on the southwest limb of the Freshwater Bay syncline, whereas on the southwest flank of Sonyakay Mountain, on the northeastern limb of the syncline, the Cedar Cove formation is missing and the Freshwater Bay formation lies directly on the Kennel Creek limestone.

The contact of the Freshwater Bay formation and the overlying Iyoukeen formation appears also to be unconformable. Bedding attitudes at the top of the Freshwater Bay formation are discordant 
with those of the limestone near the base of the Iyoukeen formation in the few places where the contact is exposed. Removal of beds by erosion from the top of the Freshwater Bay formation is difficult to demonstrate, because of the highly variable nature of the volcanic rocks.

The Freshwater Bay formation is estimated to range in thickness from about 6,500 feet near the mouth of Freshwater Bay to about 5,000 feet near the head of the bay, but it is believed to be complicated considerably by faults. In the northeast limb of the Freshwater Bay syncline, it is about 4,500 feet thick near the head of Wukuklook Creek. The formation may thin eastward toward the mouth of the creek but does not crop out there because of truncation by faulting.

Because of abrupt variations in the rocks of the Freshwater Bay formation, their description is divided below into two parts: (1) rocks on the southwest limb of the Freshwater Bay syncline, and (2) rocks on the northeast limb of the Freshwater Bay syncline.

\section{SOUTHWEST LIMB OF FRESHWATER BAY GYNCLINE}

The Freshwater Bay formation on the southwest limb of the Freshwater Bay syncline is composed of volcanic flows, tuff, breccia, and a minor amount of water-laid volcanic sedimentary rock. Although the strata vary widely in character, for descriptive purposes they may be divided into a lower greenstone member, a middle rhyolitic member, and an upper andesitic member. The members can be recognized only in the immediate vicinity of Freshwater Bay and do not apply to the northeast limb of the Freshwater Bay syncline.

\section{Lower Greenstone Member}

The lower greenstone member is exposed along the southwest shore of Freshwater Bay from East Point northwestward to Wachusett Cove and in a relatively narrow belt northwest of the mouth of Kennel Creek. It ranges in thickness from about 3,000 feet near Wachusett Cove to about 1,800 feet northwest of Kennel Creek. Because of the lack of marker beds within the member, it is not possible to distinguish changes in thickness due to faulting from those due to deposition.

Although the rock of this member is generally dark gray, it weathers to a characteristic dark greenish gray, which is an indication of alteration. The greenstone seems to represent altered mafic volcanic flows rather than pyroclastic rock, because it is rather homogeneous and displays no clastic texture. Moreover, rocks suggestive of pillow and columnar structures occur in this member. In most places the flows are massive and have indistinct boundaries.

Upon examination of thin sections, the original minerals appear to have been almost completely altered to sericite, albite, epidote, chlorite, 
calcite, and iron-ore minerals. Some of the rock is porphyritic and is composed of sericitized and albitized plagioclase phenocrysts, averaging $5 \mathrm{~mm}$ long, in a fine-grained groundmass of sericitized feldspar laths, granular epidote, interstitial chlorite, fine anhedral albite, clots of calcite, and disseminated iron-ore minerals. One thin section contains clots of chlorite suggestive of relict mafic phenocrysts embedded in a groundmass similar to that described previously. The feldspars are so finely divided by sericitization that accurate identification and differentiation from possible secondary albite is not possible.

Because the original rock types cannot be known with certainty but were probably mafic in composition, this rock is called greenstone. The term "greenstone" is used here to describe an originally mafic volcanic rock altered to a suite of secondary minerals characterized by abundant chlorite, epidote, and, in some places actinolite-hornblende.

Middle Rhyolitio Momber

The middle rhyolitic member is exposed from the north headland of Wachusett Cove to Cedar Cove, on the Redcliff Islands, and near the head of Freshwater Bay on both sides of the mouth of Freshwater Creek.

Thickness ranges from about 1,500 feet near Wachusett Cove to about 1,200 feet at the head of the bay. In contrast to the underlying greenstone member, the rhyolitic member is generally light colored, thin bedded, and highly variable. Colors are predominantly shades of red but include lesser amounts of purple, green, and gray. Most of the red-weathering rocks are also red on a fresh surface, but in a few places the fresh rock is light gray, with the red color limited to the surface.

Although most beds range in thickness from 2 inches to 2 feet, a few beds 10 feet or more in thickness were observed.

Pyroclastic rock predominates over flows and ranges from possible "welded" tuff to volcanic graywacke. In addition, a few small intrusive igneous bodies, presumably of shallow origin, are considered to be closely associated with the Freshwater Bay formation volcanism and are therefore described in this section.

Most of the pyroclastic rock is rhyolitic tuff and breccia, but the composition of fragments and matrix ranges widely. The tuff grades into volcanic graywacke and differentiation between the two rock types is difficult. Although it is beyond the scope of this work to describe the many variations of composition and texture in the pyroclastic rock of this member, a few representative types are described as follows.

Among the many color combinations are: pale-red fragments in dark-red matrix; dark-red fragments in pale-red matrix; moderate 
orange-pink fragments in dark-greenish-gray matrix; and dark-red fragments in dark-red matrix. Typical fragments are: fine-grained silicified rhyolite, partly recrystallized chert, quartz, albite-oligoclase, potassic feldspar, and baked argillite. The fragments range from less than $0.05 \mathrm{~mm}$ to more than $300 \mathrm{~mm}$ in diameter, but most fragments range from 0.5 to $4 \mathrm{~mm}$. The fragments also range from rounded to angular.

The typical rhyolitic tuff is dusky red, finely banded, and well indurated. It is grayish red on fresh surfaces and contains dusky red-purple subangular argillite fragments, ranging in length from 1 to $10 \mathrm{~mm}$, scattered in a fine-grained thinly laminated matrix. In addition, the rock appears in thin section to consist of slightly rounded euhedral orthoclase and quartz crystals, averaging $0.4 \mathrm{~mm}$ long, scattered in a fine-grained cloudy iron-rich quartzofeldspathic matrix. The matrix is composed of fine angular fragments, crystals of quartz and feldspar, and fine fragments of argillite. Although the particles of the matrix are commonly oriented subparallel to bedding, they bend around coarser fragments in a manner suggesting compaction. Visually estimated component percentages are: orthoclase grains, 20 percent; quartz grains, 10 percent; argillite grains, 5 percent; ironore mineral grains, 5 percent; and matrix, 60 percent.

Volcanic graywacke, much less abundant than tuff, is typically dusky yellow green, well indurated, medium bedded, and coarse grained. In thin section it appears to be composed of subrounded to subangular grains averaging $2 \mathrm{~mm}$ in greatest dimension; the grains, however, are poorly sorted and range from submicroscopic to $3.5 \mathrm{~mm}$. Major constituents are: very fine grained volcanic rock fragments consisting of semiopaque material, feldspar microlites and chlorite, and partly sericitized plagioclase laths ranging in composition from $\mathrm{An}_{8}$ to $\mathrm{An}_{15}$. Minor constituents are: quartzitic recrystallized chert and chloritic, quartzitic siltstone fragments. All the grains are embedded in a very fine grained cloudy micaceous matrix composed of chlorite and interlayered illite and montmorillonite. The composition of the matrix was determined by Julius Schlocker of the U.S. Geological Survey by X-ray defraction methods. Visual estimates of the component percentages are: plagioclase grains, 35 percent; rock fragments, 50 percent; and matrix, 15 percent.

Because this rock contains abundant volcanic rock fragments embedded in a well-indurated micaceous-chloritic matrix, it is volcanic graywacke in the classification of Gilbert (in Williams, and others, 1954, p. 291-294).

Flow rock is apparently less abundant than pyroclastic rock in the rhyolitic member, but no precise statement about the relative abun- 
dance of the two types can be made, owing to the difficulty of distinguishing between them in the field. Without exception, the lightgray felsitic rock showed clastic texture upon examination of thin section. No generalization as to a possible correlation between color and texture can be made, however, because of the lack of detailed sampling.

In hand specimen, the darker hued soda-rhyolite flow rock is dark reddish gray and contains fairly abundant pale-red feldspar phenocrysts, averaging $2 \mathrm{~mm}$ long, embedded in a dark-red aphanitic groundmass. In thin section the rock appears to be composed of partly resorbed euhedral phenocrysts of microperthitic potassic feldspar in a fine-grained granular groundmass of quartz, potassic feldspar, sodic plagioclase, anhedral greenish-yellow and dark-greenishblue pleochroic sodic amphibole, calcite, and iron ore minerals. The plagioclase, limited to the groundmass and perthitic intergrowths, is difficult to determine accurately. Visual estimates of component percentages are: feldspar (including potassic feldspar and plagioclase), 30 percent; quartz and plagioclase in groundmass, 25 percent; sodic amphibole, 25 percent; calcite, 5 percent; iron ore minerals, 15 percent; and sphene, trace amounts.

Several small igneous bodies intrude the rocks of the rhyolitic member. Two of the largest, described as follows, are small pluglike bodies whose true outlines are unknown because both are largely surrounded by water.

The larger of these bodies, forming Cedar Island near the middle of the southwest shore of Freshwater Bay, has a minimum diameter of 1,800 feet. The massive outcrops weather to a mottled dusky yellow and grayish olive green, but the rock on fresh surface is greenish gray.

In thin section, the rock appears to be composed of euhedral phenocrysts, averaging $1 \mathrm{~mm}$ long, of partly sericitized albite-twinned plagioclase $\left(\mathrm{An}_{30}-\mathrm{An}_{38}\right)$ and partly chloritized augite in an indistinct altered groundmass composed of plagioclase, potassic feldspar, sericite, epidote, chlorite, and iron-ore minerals. The ratio of plagioclase to potassic feldspar is about 1:1. This mineral association and texture suggests a vogesite lamprophyre (Williams and others, 1954, p. 84-92).

The smaller body of the two studied forms a narrow low rocky island about 700 feet long and 200 feet wide near the southwest shore of Freshwater Bay, about 11/2 miles southeast from the mouth of Freshwater Creek. The long dimension of the island trends northwestward, about parallel to the strike of the bedded rocks. In hand specimen, the rock is massive, medium crystalline, and pale red with 
dark-green patches on a fresh surface. It weathers pale-reddish brown.

In thin section the rock appears to have an intergranular texture composed of subhedral albite-twinned crystals of plagioclase averaging $0.5 \mathrm{~mm}$ long, slightly larger anhedral plates of potassic feldspar, and clots of chlorite, calcite, and iron-ore minerals forming pseudomorphs after euhedral amphibole crystals. The strongly cericitized plagioclase ranges in composition from $\mathrm{An}_{5}$ to $\mathrm{An}_{15}$. The potassic feldspar is strongly altered to kaolin and sericite. The ratio of plagioclase to potassic feldspar is about $1: 3$. In composition and texture this rock resembles a vogesite lamprophyre (Williams and others, 1954, p. 84-92), but the high degree of alteration precludes a definite classification.

\section{Upper andesitic member}

The upper andesitic member crops out along the northeast shore of Freshwater Bay from the cove due north of Cedar Island northwestward to the head of the bay. The total thickness cannot be measured, because the contact with the underlying rhyolitic member is covered by the waters of Freshwater Bay and the alluvium of the valley extending northwestward from the head of the bay. The minimum measured thickness is about 2,000 feet.

In outcrop the rocks of the andesitic member are variegated dark gray, green, and purple. Flows, tuff, and breccia occur in nearly equal amounts, along with lesser amounts of volcanic graywacke. The graywacke occurs chiefly as a massive conglomeratic lens at the base of the exposed section about 2,700 to 3,000 feet, stratigraphically, below the top of the andesitic member. Bedding thickness is variable and ranges from a few inches to a few tens of feet.

The flow rock commonly contains amygdales that are generally filled by either calcite or chlorite. Most of the rocks studied in thin section are almost completely altered to secondary minerals, but scattered remnants of the original mineral assemblage suggest an original andesitic composition.

One example of an altered greenish-gray flow rock in thin section appears to be composed of chloritized euhedral pyroxene and sericitized plagioclase phenocrysts in a cloudy groundmass consisting of abundant calcite, chlorite, sericitized feldspar microlites, secondary albite, and disseminated iron ore. The pyroxene is completely altered to chlorite, calcite, and possibly chalcedony. Because no original feldspar remains, it is not possible to accurately classify this rock.

The altered tuff is generally lighter in color than the flows and ranges from variegated light green, dark green, and purple to shades 
of gray. The tuff contains rounded to angular fragments of altered fine-grained volcanic rock and altered feldspar crystals. In thin section the original constituents appear to be completely altered to an indistinct mass of secondary minerals. The feldspar has been altered to sericite and fine secondary albite. Rock fragments now consist largely of sericitized feldspar microlites in a cloudy groundmass of chlorite, calcite, and iron-ore minerals. The matrix of the tuff has a similar composition, with the result that borders between rock fragments and matrix are indistinct.

Rocks in which identifiable original minerals survive are not common but include both porphyritic and nonporphyritic andesitic flows. The medium-dark-gray massive porphyritic andesite is composed of abundant dark-green euhedral pyroxene phenocrysts, averaging $5 \mathrm{~mm}$ in greatest dimension and embedded in a fine-grained groundmass. In thin section the phenocrysts appear to be augite crystals that have been replaced almost entirely by pale-green anhedral crystals of uralitic amphibole (possibly actinolitic hornblende). Often 2 or 3 amphibole crystals have replaced an individual pyroxene phenocryst. The groundmass, about 80 percent of the rock, is composed of partly sericitized plagioclase laths ranging in composition from $\Delta n_{43}$ to $A n_{46}$, anhedral shreds of green hormblende, interstitial epidote, pyrite, chlorite, and calcite. The groundmass has an intergranular texture but is cloudy and somewhat indistinct.

A nonporphyritic andesite examined in thin section showed a finegrained intergranular texture composed of partly sericitized plagioclase laths averaging $\mathrm{An}_{40}$ in composition, sparse anhedral crystals of potassic feldspar, and interstitial euhedral and anhedral green hornblende, epidote, chlorite, and iron ores. The ratio of plagioclase to potassic feldspar is about $4: 1$. Green hornblende forms nearly onethird of the total rock.

\section{NORTHEAST LIMB OF FRESHWATER BAY SYNCLINE}

The volcanic rock of the northeast limb of the Freshwater Bay syncline appears more homogeneous than that of the southwest limb. It consists predominately of massive porphyritic andesite flows with minor amounts of flow breccia. Graywacke, argillite, and limestone, in addition to the volcanic rock, form a thick sequence at the top of the section in the northwestern part of the outcrop belt. Thinner units of limestone, graywacke, and argillite also occur near the middle of the volcanic sequence. The maximum thickness of the formation in the north limb is about 4,500 feet, in the northwestern part of the area mapped. The formation wedges out to the southeast between the headwaters and the mouth of Wukuklook Creek. 
The predominant volcanic rock type is a medium-dark-gray porphyritic andesite composed of a variable amount of plagioclase phenocrysts in a fine-grained or aphanitic groundmass. The rock weathers yellowish green and dark olive gray.

In thin section the andesite appears to consist of phenecrysts of plagioclase, ranging from 1 to $6 \mathrm{~mm}$ long, in a fine-grained cloudy trachytic groundmass composed of andesine microlites, anhedral green hornblende, calcite, chlorite, and iron-ore minerals. In some specimens mafic minerals are completely altered to chlorite, calcite, and iron-ore minerals. One thin section shows partly sericitized euhedral phenocrysts of plagioclase, ranging in composition from $\mathrm{An}_{15}$ to $\mathrm{An}_{25}$ in a xenomorphic recrystallized groundmass composed largely of sodic oligoclase and quartz. The mafic minerals in this specimen are completely altered to chlorite, epidote, and iron-ore minerals.

Limestone, graywacke, and argillite form a sedimentary member about 1,000 feet thick at the top of the Freshwater Bay formation near the north border of the map area. This lithic unit, not recognized on the southwest limb of the Freshwater Bay syncline, is described in detail in the stratigraphic section that follows.

Southeastward along the strike in the headwaters of Wukuklook Creek, calcareous conglomerate, breccia, and sandstone occupy about the same stratigraphic position as the limestone, graywacke, and argillite to the northwest. (See secs. 5 and 6, pl. 2). These coarse clastic rocks contain fragments of pink chert, dark-gray limestone, and light-gray fine-grained volcanic rock embedded in calcareous matrix. The rocks weather to a dark brownish gray rough surface; beds range in thickness from 1 to 3 feet and are frequently cross stratified. Because these rocks contain abundant calcareous matrix, they may grade laterally into limestone.

The standard section of the Freshwater Bay formation is given:

Standard section on northeast limb of Freshwater Bay syncline

Iyoukeen formation:

Lower limestone member :

Limestone, dark-gray, fine-grained in beds $0.1-0.5 \mathrm{ft}$. thick

Unconformity (?)

Freshwater Bay formation:

Thiokness (feet)

Argillite and graywacke; dark-gray noncalcareous to slightly calcareous argillite and dark-gray calcareous medium-grained graywacke; beds 5-20 ft thick; 80 percent argillite

Graywacke and argillite; medium-gray conglomeratic calcareous coarse-grained graywacke composed of angular grains of chert; dark-gray fine-grained volcanic rock in calcite-rich matrix in beds 2-5 ft thick ; lesser amounts of dark-gray graded-bedded mediumgrained graywacke and medium-dark-gray siliceous argllite in beds averaging $1 \mathrm{ft}$ thick 
Standard section on northeast limb of Freshwater Bay syncline-Continued

Freshwater Bay formation-Continued

Thickness

Limestone and argillite; dark-gray, reddish-yellow, and mediumgray-weathering fine-grained limestone in cobbly beds $0.3-1 \mathrm{ft}$ thick ; dark-gray reddish-brown-weathering siliceous argillite increases in abundance toward top (as much as 50 percent); 30 ft. thick dark-gray porphyritic (plagioclase) andesite flow near top of unit

Total thickness of the upper sedimentary member

Andesite, dark-gray, weathers brownish gray, fine- to coarse-porphyritic, massive flows; euhedral plagioclase $1-10 \mathrm{~mm}$ long in aphanitic groundmass

Limestone, dark-brownish-gray, fine-grained, in beds $0.1-0.2 \mathrm{ft}$ thick; contains reddish-brown siliceous argillite in a very thin irregular network

Argillite and graywacke thinly interbedded; dark-brownish-gray noncalcareous argillite; grayish-black noncalcareous fine-grained graywacke; beds average $0.1 \mathrm{ft}$ thick ; minor amounts of mediumgray chert

Andesite, medium-dark-gray to dark-gray, porphyritic; tlows and flow breccia; euhedral plagioclase phenocrysts averaging $5 \mathrm{~mm}$ in length in an aphanitic groundmass; minor flow breccia contains angular to rounded andesite fragments, averaging $1 \mathrm{ft}$ across, in an andesite matrix; beds massive and indistinct

Section interrupted by igneous intrusion

Andesite, dark-gray, aphanitic, anygdaloidal ; calcite amygdales; poorly exposed

Total thickness of Freshwater Bay formation (excluding inter-

val occupied by igneous intrusion) $4,450+$ Unconformity (?)

Kennel Creek limestone :

Argillite, dark-reddish-gray, poorly exposed.

\section{AGE AND CORRELATIOH}

The predominantly volcanic strata unconformably overlie the Middle and Late(?) Devonian Cedar Cove formation and are overlain by the Mississippian Iyoukeen formation. Although no fossils have been collected from this formation in the Freshwater Bay area, fossils indicative of a Late Devonian age have been found in clastic rocks intercalated with volcanic rocks continuous with this formation cropping out at Port Frederick, about 15 to 20 miles northwest of the type locality on Freshwater Bay. At Port Frederick, water-laid fragmental sandstone is interbedded in the volcanic sequence. Marine fossils from this sandstone are of Late Devonian age (late Frasnian equivalents). The fossil assemblage is composed predominantly of brachiopods and molluses and characteristically has numerous speci- 
mens of Cyrtospirifer. At another locality in Port Frederick, a coralline-brachiopod faunule has been collected from limestone that is considered a part of the Freshwater Bay formation. This assemblage also appears to be of Frasnian age.

\section{MISSISSIPPIAN ROCKS}

\section{IYOUKOHEN FORMATION}

The thick sequence of cherty limestone and shale typically exposed on Iyoukeen Peninsula, the northwest shore of Iyoukeen Cove, and inland to the northwest on the ridges drained by Gypsum and Seal Creeks is here named the Iyoukeen formation. The limestone exposed on Iyoukeen Peninsula and the northwest shore of Iyoukeen Cove belongs to the upper limestone member of the formation. Owing to structural complexity, the middle and the lower limestone members are not present in the vicinity of Iyoukeen Cove. Typical sections of the upper, middle, and lower members crop out on the ridges drained by Gypsum and Seal Creeks.

\section{DISTRIBUTION AND TOPOGRAPHIC EXPREGSION}

The rocks of the Iyoukeen formation form an outcrop belt ranging in width from $21 / 2$ to $31 / 2$ miles and extending from Iyoukeen Cove northwestward to the north edge of the map area in the vicinity of the headwaters of Spasski Creek. The outcrop belt is interrupted by the Gypsum Creek quartz monzonite and is displaced by several faults. The resistant upper limestone member forms a broad, U-shaped northwestward-trending topographic trough whose axis is roughly parallel to Gypsum Creek at the southeast end and to the headwaters of Spasski Creek at the northwest end. This trough, a physiographic expression of the Freshwater Bay syncline, is flanked by high outward-facing cuestas, except where interrupted by faulting or intrusive rocks. The middle member forms slopes and subdued topography, whereas the lower limestone forms low, minor ridges.

\section{GTRATIGRAPHY AND PETROGRAPHY}

The Iyoukeen formation is the youngest pre-Quaternary rock unit in the Freshwater Bay area. Its upper contact is apparently an erosional surface cut in the upper limestone member. The contact with the underlying Freshwater Bay formation appears to be unconformable. Beds of the underlying Freshwater Bay formation appear to be truncated below the base of the Iyoukeen formation at several localities. Removal of units by erosion from the top of the Freshwater Bay formation cannot be demonstrated stratigraphically, because of 
the highly variable nature of the volcanic rock forming most of the formation.

The upper limestone member of the Iyoukeen formation is in contact with the Kennel Creek limestone near the lower part of the Wukuklook Creek; both the Freshwater Bay and Cedar Cove formations are missing. The Kennel Creek limestone probably has been thrust to the southwest and has overridden the Cedar Cove formation, the Freshwater Bay formation, and, possibly, the lower and middle members of the Iyoukeen formation. (See sec. E-E', pl. 1 and sec. 7, pl. 2.)

The Iyoukeen formation is divided into an upper limestone member, a middle member, and a lower limestone member. The upper limestone member, more than 3,000 feet thick, is characterized by fossiliferous dark- and light-gray medium-bedded limestone with dark-gray thin irregular nodular chert lenses. Dark-gray limestone is predominant. The middle member is composed predominantly of dark-gray to grayish-black sparsely fossiliferous shale with a few beds of graywacke and limestone. The shale becomes more calcareous toward the northwest and, on the northeast limb of the Freshwater Bay syncline near the north border of the map area, grades into medium-gray yellowweathering shaly limestone. The thickness of the middle member ranges from 500 feet on the northeast limb of the Freshwater Bay syncline to 750 feet on the southwest limb. The lower limestone member consists mainly of dark-gray fossiliferous fine-grained thinbedded limestone with a few dark-gray thin regular chert beds. The lower limestone member ranges in thickness from 200 feet on the southwest limb of the Freshwater Bay syncline to 600 feet on the northeast limb. Part of the increase in thickness of the lower limestone member toward the north appears to be at the expense of the middle member, which becomes more calcareous and thinner in that direction.

The total exposed thickness of the Iyoukeen formation decreases to the northwest owing to erosion of the southeastward-plunging Freshwater Bay syncline. The maximum exposed thickness of the Iyoukeen formation is probably less than 4,500 feet, but the total thickness cannot be measured at any one locality.

The dominant rock type of the Iyoukeen formation, a dark-gray to grayish-black fine- to medium-grained limestone, contains abundant calcareous shell debris and commonly emits a strong fetid odor when broken. Less common light-brownish-gray medium- to coarsegrained bioclastic limestone appears to be composed entirely of shell debris. In contrast to the low porosity of the dark limestone, the bioclastic limestone contains scattered fine pores. Insoluble residue, obtained from dissolving a quantity of the normal dark limestone in 
warm dilute hydrochloric acid, comprises about 7 percent of the total rock by weight. This residue consists of finely divided quartz, silicified fossil remains, and fine black carbonaceous material. The black carbonaceous material is largely responsible for the dark color of the limestone.

\section{GYPSUM DEPOSITE}

Gypsum deposits at Iyoukeen Cove are the only known mineral deposits of commercial importance in the Freshwater Bay area.

The gypsum, associated with buff or cream-colored limestone breccia and dark-gray, cherty limestone, occurs at the top of the upper limestone member in the core of the Freshwater Bay syncline. Owing to the southeastward plunge of the syncline, the gypsum and associated limestone occupy the highest stratigraphic position of any of the exposed rock units in the synclinal fold. C. W. Wright (in Brooks, 1908, p. 124) assumed that the gypsum deposits and associated breccia were of sedimentary origin and regarded the gypsum as Permian or Triassic in age. However, fossils of Late Mississippian age, collected from the upper limestone member of the Iyoukeen formation, represent the youngest fauna known from the area. Flint and Cobb (1953) suggested that the gypsum may be hydrothermal in origin and may have been deposited in brecciated fault zones within the limestone. However, owing to poor outcrops and much alluvial cover, they did not reach a conclusion as to which hypothesis of origin was more probable. The gypsum and buff or cream-colored limestone breccia are not recognized elsewhere in the Iyoukeen formation; their restriction to the highest part of the formation suggests stratigraphic control. On the other hand, the proximity of the Gypsum Creek quartz monzonite lends evidence to the hydrothermal hypothesis.

The gypsum deposits were first reported in 1902 and were worked until 1923; the mines are now abandoned. The largest mine was located on Gypsum Creek about three-quarters of a mile upstream from its mouth. Less extensive mining operations were carried out on the shore of the small bay, about three-quarters of a mile southwest of the mouth of Wukuklook Creek. Flint and Cobb (1953) supplied detailed information about the gypsum deposits and the history of their development and operation.

\section{MEASURED BECTIONS}

The first of the following measured sections is considered to be the thickest and most complete section of Iyoukeen formation exposed in the Freshwater Bay area. Because the middle and lower members are involved in a complex faulting at this locality, a section in the northern drainage of Seal Creek was chosen as representative of the lower two members. 
The standard section of the Iyoukeen formation is given :

\section{Standard section}

Covered.

Iyoukeen formation (incomplete) :

Upper limestone member (incomplete) :

Thickness

(feet)

7. Limestone, interbedded light-gray and light-brownish-gray; light-gray medium-grained sugary limestone with scattered fine porosity ; light-brownish-gray medium- to coarsegrained clastic limestone; beds 3-10 ft thick; sparse darkgray nodular chert, partly bleached to light-brownish-gray, in lenses $0.3-0.5 \mathrm{ft}$ thick

6. Limestone and chert; dark-gray fine-grained limestone in 2-4-ft thick beds and dark-gray irregular beds of nodular chert 0.1-0.3 ft thick ; cross beds of chert in many places_-

5. Limestone, medium-dark-gray, fine-grained, in beds averaging $2 \mathrm{ft}$ thick; contains abundant lithostrotionoid and solitary corals, lesser amounts of dark-gray irregular nodular chert in lenses $0.1-0.3 \mathrm{ft}$ thick, and light-brownishgray medium-grained bioclastic limestone with abundant crinoid columnals, in beds averaging $3 \mathrm{ft}$ thick

4. Limestone, similar to unit 5 but partly altered to light-gray medium- to coarse-grained marble with nodular chert lenses partly altered to light-gray fibrous tremolite and calcite masses of same shape; lithostrotionoid corals common

3. Chert, grayish-brown and dark-gray, in cobbly beds averaging $0.3 \mathrm{ft}$ thick

2. Limestone and chert interbedded; medium-dark-gray finegrained limestone in 2-4-ft beds and dark-gray, grayish brown-weathering nodular chert in lenses $0.3-0.4 \mathrm{ft}$ thick; 75 percent limestone; abundant solitary corals; USGS18371-PC from level $100 \mathrm{ft}$ below top

1. Limestone, chert, and argillite, very thinly interbedded; dark-gray fine-grained limestone; dark-gray nodular chert and grayish-black shaly siltstone in beds 0.1-0.2 ft thick; abundant brachiopods ; USGS-18372-PC from top $10 \mathrm{ft}$.-

Thickness of the upper limestone member

Middle member, Iyoukeen formation :

Shale, grayish-black, massive, noncalcareous, subfissile to conchoidal; abundant brachiopods and solitary corals; USGS18374-PC about $400 \mathrm{ft}$ from the top; USGS-18375-PC $500 \mathrm{ft}$ from top of member. 
Section along northeastward-trending ridge near north border of map, about 9.5 miles north of the mouth of Seal Creek

Eroded surface.

Iyoukeen formation (incomplete):

Upper limestone member (incomplete) :

Thickness

Limestone, medium-dark-gray, medium-grained; beds $1-4 \mathrm{ft}$ thick; sparse interbedded dark-gray nodular chert beds $0.1-$ $0.5 \mathrm{ft}$ thick; lithostrotionoid and solitary corals common; forms prominent ridge; USGS-18385-PC from bottom $20 \mathrm{ft}$; USGS-18386-PC $150 \mathrm{ft}$ above base

Limestone and chert; medium-dark-gray medium-grained limestone beds $0.1-3 \mathrm{ft}$ thick and dark-gray nodular chert beds $0.1-0.5 \mathrm{ft}$. thick; chert forms as much as 20 percent of unit; a few brownish-gray coarse-grained bioclastic beds; solitary corals common; a few lithostrotionoid corals and brachiopods

Thickness of upper limestone member

Middle member :

Limestone, chert, and argillite; medium-gray light-grayishyellow-weathering fine-grained argillaceous shaly limestone; grades downward into thinly interbedded dark-gray nodalar chert, grayish-black fine-grained limestone, and grayish-black calcareous argillite; near base, beds average $0.5 \mathrm{ft}$. in thickness; forms smooth nonresistant slope

Lower limestone member :

Limestone, dark-gray, fine-grained; cobbly beds 1-2 ft. thick; sparse beds of nonnodular dark-gray chert and reddish-gray argillite $0.1-0.5 \mathrm{ft}$. thick; brachiopods and syringoporoids common ; USGS-18383-PC 100 ft. above base ; USGS-18384PC $150 \mathrm{ft}$. above base

Thickness of Iyoukeen formation $2,000+$

\section{AGE AND CORRELATION}

Rocks exposed on the Iyoukeen Peninsula represent only the upper limestone member and the upper part of the middle member. Older beds crop out on both flanks of the Freshwater Bay syncline in the hills northwest of the peninsula. The entire formation is of Mississippian age.

The lower member has yielded few fossils. Dominant elements of the fauna are: the coral Syringopora, spiriferoid and chonetid bachiopods, and gastropods including Straparollus (Euomphalus) sp.

Fossils are more common in the middle member and indicate a more diversified fauna. In addition to the fossils found in the lower member, solitary rugose corals, productoid brachiopods, and Leptaena cf. L. analoga (Phillips) are found. 
The lower two members are of Early Mississippian age and contain fossils similar to those collected from the Kayak shale and Wachsmuth limestone in northern Alaska (Bowsher and others, 1957, p. 5). The faunas also resemble, in a general way, those of the Lodgepole limestone in Montana and the Banff formation in Alberta.

The upper member, composed of massive cherty limestone beds, is extremely fossiliforous. Lithostrotionoid corals and a variety of large horn corals are found at nearly every outcrop. The only other genus widely represented is Gigantoproductus, a large brachiopod that in so many places is associated with the coralline assemblages of Late Mississippian age in Alaska and the Pacific Northwest.

These fossils indicate rather close correlation with the Alapah limestone of northern Alaska, the Rundle formation of Alberta, and the Brazer formation as it has been interpreted in southeastern Idaho (Mansfield, 1927, p. 63-71).

No beds of definitely post-Mississippian age are known to be in the Freshwater Bay area. The gypsiferous strata that appear to overlie the fossiliferous beds of the upper limestone may be younger, but no fossils have been recovered from them.

\section{QUATERNARY DEPOSITS}

Undifferentiated gravel, sand, silt, and talus debris are mapped as a single unit on plate 1. Glacial, alluvial, and colluvial deposits were not studied in detail or separated in mapping. To a large extent the boundaries of the areas included in this map unit were delineated from aerial photographs.

\section{INTRUSIVE IGNEOUS ROCKS}

Five plutonic igneous bodies crop out within or border on the Freshwater Bay area. The two larger bodies range from quartz monzonite to granite in composition. The three smaller bodies range in composition from diorite to quartz diorite. Significant data concerning these plutons are summarized in table 2. Not included in this summary are the small intrusive bodies associated with volcanic rock of the Freshwater Bay formation and described with the rocks of this formation. The classification of igneous rocks of Williams and others $(1954$, p. 3-149) has been followed. 
TABLE 2.-Summary of plutonic igneous bodies in the Freshwater Bay area, Chichagof Island, Alaska

\begin{tabular}{|c|c|c|c|}
\hline Description & Location & Youngest strata intruded & Age of intrusion \\
\hline $\begin{array}{l}\text { Gypsum Creek quartz } \\
\text { monzonite (horn- } \\
\text { blende-biotite), area }\end{array}$ & $\begin{array}{l}\text { North and west drain- } \\
\text { age of Gypsum Creek. }\end{array}$ & $\begin{array}{l}\text { Upper limestone mem- } \\
\text { ber, Iyoukeen forma- } \\
\text { tion. }\end{array}$ & $\begin{array}{l}\text { Post-Upper Mississip- } \\
\text { pian and pre-Quater- } \\
\text { nary. }\end{array}$ \\
\hline $\begin{array}{l}\text { Hornblende granite, } \\
\text { highly variable, only } \\
\text { border mapped; area } \\
\text { unknown. }\end{array}$ & $\begin{array}{l}\text { Upper drainage of } \\
\text { Kennel Creek and } \\
\text { Pavlof River. }\end{array}$ & $\begin{array}{l}\text { Kennel Creek lime- } \\
\text { stone (only part } \\
\text { within area observed). }\end{array}$ & $\begin{array}{l}\text { Post-Middle Devonian } \\
\text { and pre-Quaternary. }\end{array}$ \\
\hline $\begin{array}{l}\text { Hormblende-augite } \\
\text { diorite, area about } 0.75 \\
\text { square mile. }\end{array}$ & $\begin{array}{l}\text { West of Seal Creek, } \\
1.5 \text { miles north of the } \\
\text { head of Freshwater } \\
\text { Bay. }\end{array}$ & $\begin{array}{l}\text { Upper limestone mem- } \\
\text { ber, Iyoukeen for- } \\
\text { mation. }\end{array}$ & $\begin{array}{l}\text { Post-Upper Mississip- } \\
\text { pian and pre-Qua- } \\
\text { ternary. }\end{array}$ \\
\hline $\begin{array}{l}\text { Hornblende-biotite } \\
\text { quartz diorite, area } \\
\text { about } 0.6 \text { square mile. }\end{array}$ & $\begin{array}{l}\text { Near headwaters of } \\
\text { Iyouktug Cresk, } \\
\text { about } 1 \text { mille south of } \\
\text { the north border } \\
\text { of map. }\end{array}$ & $\begin{array}{l}\text { Freshwater Bay forma- } \\
\text { tion. }\end{array}$ & $\begin{array}{l}\text { Post-Upper Devonian } \\
\text { and pre-Quaternary. }\end{array}$ \\
\hline $\begin{array}{l}\text { Hornblende-biotite- } \\
\text { quartz diorite, area } \\
\text { about } 0.3 \text { square mlle. }\end{array}$ & $\begin{array}{l}\text { Near head waters of } \\
\text { Iyouktug Creek, } \\
\text { about } 1 \text { mile north- } \\
\text { west of previous } \\
\text { location. }\end{array}$ & $\begin{array}{l}\text { Freshwater Bay for- } \\
\text { mation. }\end{array}$ & $\begin{array}{l}\text { Post-Upper Devonian } \\
\text { and pre-Quaternary. }\end{array}$ \\
\hline
\end{tabular}

The age of intrusion cannot be closely determined in the Freshwater Bay area. The youngest strata intruded range in age from Middle Devonian to Late Mississippian. The oldest strata unaffected by the intrusions are the unconsolidated Quaternary deposits that partly cover the erosion surface on the top of the plutons. Thus field relations in the Freshwater Bay indicate that the most recent intrusion must have occurred after the deposition of the Upper Mississippian limestone and before the deposition of the Quaternary beds. Whether the plutons that intrude rocks no younger than Devonian are approximately contemporaneous with those intruding the Upper Mississippian limestone cannot be determined from field evidence.

GYPSUM CREER QUARTZ MONZONITE

DISTRIBUTION AND LOCATION

Quartz monzonite in a pluton at the head of Gypsum Creek north of Freshwater Bay is here named the Gypsum Creek quartz monzonite. It forms an elongate west-northwestward-trending outcrop that is about 5.5 miles long and that averages 0.75 mile wide. The northern and northwestern tributaries of the creek cut largely into the quartz monzonite. The pluton occupies the central part of the Freshwater Bay syncline and is almost entirely surrounded at the surface by limestone of the upper part of the Iyoukeen formation. Its age can be determined no closer than post-Late Mississippian and preQuaternary. 


\section{PETROGRAPHY}

The normal quartz monzonite in hand specimen is light gray, equigranular, medium grained, and rather homogeneous. This rocktype forms the bulk of the pluton, and border phases compose a relatively minor percentage of the exposed rock. In thin section the normal quartz monzonite shows a hypidiomorphic granular texture consisting of the following minerals: anhedral slightly sericitized oligoclase ranging from $A n_{30}$ at the core to $A n_{15}$ near the edge; large (as much as $3 \mathrm{~mm}$ long) anhedral slightly kaolinized potassic feldspar phenocrysts; euhedral green hornblende; frayed plates of reddishbrown biotite; and minor amounts of sphene, muscovite, apatite, and iron-ore minerals. In some specimens the hornblende is partly altered to biotite that, in turn, is partly altered to chlorite. Average visual estimates of mineral components are: plagioclase, 42 percent; potassic feldspar, 25 percent; quartz, 18 percent; biotite, 7 percent; hornblende, 6 percent; and minor accessories, 3 percent. An average plagioclase-potassic feldspar ratio of less than 2:1 places these rocks well within the quartz monzonite range (Williams and others, 1954, p. 121, 131). The potassic feldspar, either untwinned or carlsbad twinned, shows little or no perthitic intergrowth.

The border facies of Gypsum Creek quartz monzonite range considerably in composition and texture within short distances. $\mathbf{A}$ few of the more important variants are described as follows.

Diopside-bearing monzonite and diorite occur along the edge of the pluton near the limestone contact at the headwaters of the tributary to Gypsum Creek which trends N. $70^{\circ} \mathrm{W}$. These rocks are highly variable both in composition and grain size. In hand specimen they are light gray with prominent medium-green diopside crystals ranging from 0.5 to $1 \mathrm{~mm}$ in length. Thin sections show a hypidiomorphic granular texture composed of euhedral diopside and green hornblende, laths of plagioclase ranging from $A_{25}$ to $A_{3}$, anhedral grains of potassic feldspar, shreds of dark-brown biotite and minor epidote, chlorite, sphene, and sericite. In some sections the hornblende has partly replaced the pyroxene, which may in part be diopsidic augite.

A small granophyric apophysis was observed within the upper limestone member of the Iyoukeen formation near the northern contact of the pluton at the head of the tributary of Gypsum Creek which trends $\mathrm{N} .70^{\circ} \mathrm{W}$. In hand specimen this rock is very light gray to white, porphyritic, and fine grained. In thin section it appears to be composed of euhedral to anhedral quartz, potassic feldspar, and oligoclase phenocrysts-as much as $1 \mathrm{~mm}$ long-in a wormy granophyric intergrowth of quartz and potassic feldspar and a fow fine shreds of 
biotite and muscovite. The average grain size of the rock is about $0.06 \mathrm{~mm}$. A plagioclase-potassic feldspar ratio of about 1:4 indicates that the rock is probably granitic.

Another leucocratic facies occurs within the northern border of the pluton, about 1 mile southeast of the granophyre. This rock is white and generally medium grained but has considerable variation in grain size. In thin section it appears to be a hypidiomorphic granular rock composed of a few euhedral plagioclase and anhedral quartz crystals surrounded largely by a plagioclase-quartz myrmekite. The remaining mineral components, less than 5 percent, are sphene, zircon, and chlorite. The grain size ranges from 0.35 to $1 \mathrm{~mm}$. The plagioclase generally displays albite twinning and is slightly sericitized; its composition ranges from $A n_{16}$ to $A n_{20}$. The leucocratic character of the rock and the lack of potassic feldspar suggest its classification as a leucocratic diorite or trondhjemite (Williams and others, 1954, p. 109-110).

\section{CONTACT METAMORPHISM}

The zone of contact metamorphism of the Gypsum Creek pluton is relatively narrow. Limestone, which forms most of the intruded country rock at the surface, is recrystallized for several tens of feet away from the intrusive contact. The actual contact, however, between metasedimentary and plutonic igneous rocks is sharp. Wollastonite marble occurs within a few feet of the contact, whereas tremolite marble is more common at greater distances. Tremolite-bearing marble is common in the upper limestone member exposed along the ridge south of the upper part of Gypsum Creek even though in places this exposure is more than a mile from the surface igneous contact. The pluton probably underlies this ridge at a relatively shallow depth. Nodular chert in the limestone on this ridge is altered to a mixture of tremolite needles and calcite. The altered nodules frequently retain a chert core.

Other minerals observed in small deposits at or near the contact of the pluton and limestone are: white euhedral diopside crystals, massive redish-brown anhedral andradite garnet, epidote, and minor amounts of iron-ore minerals (mostly pyrite). These tactite deposits are sparse and are only a few inches thick at most.

\section{PLUTON AT THE HEAD OF KENNEL CREEK}

The border zone of what appears to be a major plutonic intrusive body crops out for a distance of about 3.5 miles along the southwest margin of the map area in the upper drainage of Kennel Creek. The size of this body is not known, but exploratory traverses indicate that it may extend several miles to the southwest. The border zone rock 
is extremely variable both in composition and texture and cannot be considered characteristic of the plutonic body as a whole. Individual rock types are intertongued on such a small scale that no attempt was made to map them separately.

In general, the rock is rich in potassic feldspar that is commonly perthitic and includes large anhedral grains of microcline. The remaining constituents are: zoned plagioclase ranging from about $\mathbf{A n}_{35}$ in cores to $\mathrm{An}_{15}$ near the edge; quartz (generally more than 20 percent) ; green hornblende (generally euhedral); and minor amounts of zircon, sphene, apatite, biotite (after hornblende), chlorite, and ironore minerals. These components range widely in proportions and in grain size. The rock ranges from normal hypidiomorphic granular medium-grained granite containing less than 10 percent mafic minerals to very coarse grained hornblende-potassic feldspar-plagioclase-epidote pegmatitic rock in which the hornblende comprises more than 70 percent of the total rock. In the pegmatitic rock the hornblende is in elnogate euhedral crystals, averaging 2 inches long, and the othar minerals fill the angular interstices.

One exception to the general potassic-rich composition of the border facies is a normal-appearing hornblende diorite. It exhibits a medium-grained hypidiomorphic granular texture composed of zoned plagioclase laths ranging in composition from $\mathbf{A n}_{85}$ at the core to $\mathbf{A n}_{15}$ near the edge; minor interstitial quartz; euhedral green hornblende; and minor sphene, rutile, zircon, iron ore-minerals, and augite (partly altered to hornblende). With the possible exception of the cores of the plagioclase crystals, there is no potassic feldspar. The cores, stained yellow by the potassium cobaltinitrite stain method, are probably composed of potassic feldspar. According to Williams and others $(1954$, p. 131), the mantling of oligoclase around an orthoclase core (rapakivi texture) may indicate the basification of partly crystallized magma by assimilation of andesitic wall rocks. Certainly the dioritic facies in which the rapakivi texture occurs is more basic than the other border facies examined and may be a basification product.

\section{CONTACT METAMORPHISM}

Thinly laminated alternate light- and dark-gray argillite and the overlying massive Kennel Creek limestone are intruded by the pluton north of the valley of Kennel Creek. Along this contact the argillite occurs both at the margin of the pluton and within it as sliverlike roof pendants, whereas the limestone is largely confined to the border zone itself. The contact between plutonic igneous rock and metasedimentary rock is sharp.

The width of the contract zone is not accurately known because of poor exposures, but it appears to be at least several tens of feet wide. 
At the contact the argillite has been converted to a light- and darkbanded fine-grained hornblende-biotite-oligoclase hornfels containing variable amounts of quartz. The dark bands are rich in hornblende and biotite and represent former claystone laminae, whereas the light bands are rich in feldspar and quartz and represent former siltstone or very fine grained sandstone.

The massive limestone near the contact has been recrystallized to a white very coarse grained marble with an average grain size of about $10 \mathrm{~mm}$. The grain size of the marble appears to decrease away from the contact. Calesilicate minerals were not observed in the marble.

\section{SMALL PLUTONS}

Three small plutons crop out northeast of the head of Freshwater Bay. The shape and contact relations of these plutons are not accurately known owing to the lack of exposures, but, in general, they appear to be crosscutting pluglike bodies.

The largest of the three plutons crops out near the crest of the northwestward-trending ridge about 1.5 mile north of the head of Freshwater Bay near the headwaters of Seal Creek. It intrudes the limestone and shale of the Iyoukeen formation and probably the volcanic rock of the Freshwater Bay formation, forming an outcrop about 1 mile long 0.75 mile wide.

In hand specimen the normal rock of this pluton is medium gray and medium grained with prominent hornblende and augite phenocrysts averaging about $1 \mathrm{~mm}$ in diameter. In addition, there is a greenish-gray finer grain phase in which the mafic minerals have indistinct borders and are moderate green.

In thin section the normal rock appears to be a diorite with a nearly panidiomorphic-granular texture. It contains euhedral phenocrysts of brownish-green hornblende and slightly uralitized augite, ranging from 1 to $2 \mathrm{~mm}$ in length, in a groundmass of slightly smaller laths of zoned partly sericitized plagioclase, ranging in composition from $\mathrm{An}_{35}$ to $\mathrm{An}_{40}$, with minor amounts of dark-reddish-brown biotite (after hornblende), chlorite, apatite, and iron-ore minerals. Visual estimates of the mineral component percentages are: plagioclase, 60 percent; hornblende, 25 percent; augite, 5 percent; biotite, 3 percent; and all others 7 percent.

In thin section the greenish-gray phase appears to have been strongly uralitized. The euhedral augite crystals have been altered almost completely to a pale-green amphibole. This amphibole occurs as anhedral patches in and around the remnants of the augite crystals. No primary hornblende is present in this phase, but the plagioclase and minor accessory minerals are the same as those of the normal diorite. 
Although the borders of this pluton are poorly exposed, the contact with limestone and shale of the Iyoukeen formation was observed in a few places and appears to be sharp. In and near the contact the limestone has been recrystallized to marble that, in places, is tremolite bearing. Small, sparse deposits of reddish-brown andradite garnet, epidote, scapolite, pyrite, and minor amounts of magnetite, generally not over a few inches wide, were also observed in and near the contact of the marble and diorite. Where the diorite has intruded shale, the shale has been converted to a dark-gray hornblende-biotite hornfels.

Two smaller plutons crop out on subparallel north-northeastwardtrending ridges about 4 miles northeast of the diorite near the headwaters of Iyouktug Creek. The northwesternmost of the two bodies intrudes the lower part of the Freshwater Bay formation; the southeastern body intrudes along the contact between the Freshwater Bay formation and the Kennel Creek limestone. Each pluton crops out for about 1,000 feet along the ridges on which they are exposed, but because of poor exposures other dimensions were not determined.

Typically the rock of both plutons is quartz diorite, which in hand specimen is medium gray, medium grained, and equigranular with conspicuous dark grains of hornblende and biotite. In thin section a typical specimen shows a hypidiomorphic granular texture consisting of: laths of zoned albite-twinned moderately sericitized plagioclase; interstitial clear quartz; anhedral bluish-green hornblende, slightly altered to biotite; dark-reddish-brown shreds of biotite; and minor amounts of sphene, apatite, and iron-ore minerals. Visual estimates of mineral component percentages are: plagioclase, 50 percent; quartz, 15 percent; hornblende, 20 percent; biotite, 10 percent; and all others 5 percent. The plagioclase averages about $\mathrm{An}_{50}$ near the center of grains and $A n_{35}$ near the edges. Average grain size is about $0.75 \mathrm{~mm}$ in diameter.

Because the contracts of both plutons are poorly exposed, little in the way of contact metamorphism was observed. The southeastern pluton has recrystallized the Kennel Creek limestone to a white medium crystalline marble near the contact, but the width of the contact zone is not known.

\section{DIRES AND STLLS}

Numerous dikes and sills, some of post-Mississipian age, intrude the rocks of the Freshwater Bay area. Descriptions of some of the more common types are summarized as follows.

\section{ANDESTME DTKES AND BTLS}

A complex of dikes and sills, ranging from 6 inches to 30 feet in thickness intrudes the middle member of the Iyoukeen formation on 
the first ridge northeast of Freshwater Bay. Most of these rocks are andesite, but a few felsite dikes occur among them. In general, the dikes strike $\mathrm{N} .25^{\circ} \mathrm{W}$. and dip $30^{\circ} \mathrm{NE}$., whereas the sills, in paralleling the bedding, strike N. $30^{\circ} \mathrm{E}$. and dip $30^{\circ} \mathrm{SE}$. There is, however, much irregularity of attitude.

In hand specimen the andesitic rock is dark grayish brown and consists of conspicuous euhedral hornblende phenocrysts, averaging about $3 \mathrm{~mm}$ long, embedded in an aphanitic groundmass. Thin sections show phenocrysts of strongly sericitized plagioclase and euhedral greenish-brown hornblende in a groundmass of stubby microlites of plagioclase and hornblende, together with interstitial chlorite and sericite. The plagioclase crystals are zoned from $A n_{30}$ to $\mathrm{An}_{40}$ near the core to $\mathrm{An}_{15}$ to $\mathrm{An}{ }_{20}$ near the edges; albite twinning is common. The hormblende is mostly brown with green rims and spots; it is commonly altered to chlorite.

The felsite is aphanitic, very light gray on fresh fracture and brownish red on weathered surfaces. In thin section it appears to consist of irregular remnants of feldspar phenocrysts in a very fine grained cloudy felty groundmass of sericite and disseminated pyrite. The feldspar is too much altered to be identified. Fine mosaic quartz occurs both in veinlets and in the rock surrounding the veinlets.

\section{SPESSARTITE LAMPROPHYRE}

A single sillike intrusive igneous body crops out $31 / 2$ miles north of the mouth of Seal Creek in a narrow saddle on a major northeastward-trending ridge. (See pl. 1.) The body is about 150 feet thick and 1,000 feet long and intrudes the Iyoukeen formation near the contact between the middle member and the lower limestone member. Contact relations are not clear, but the intrusion appears to parallel the bedding of the sedimentary rock and may be a sill.

In outcrop the igneous rock is not readily differentiated from the limestone and shale that it intrudes. Both igneous and sedimentary rocks near the contact weather with rough brownish-gray surfaces.

In thin section the igneous rock displays a porphyritic texture consisting of abundant needles of reddish-brown hornblende in a cloudy indistinct groundmass composed of anhedral oligoclase, indistinct potassic feldspar, hornblende microlites, chlorite, and iron-ore minerals. The plagioclase-potassic feldspar ratio is about $4: 1$. Both composition and texture indicate a spessartite lamprophyre (Williams and others, 1954, p. 84-89).

The limestone for several tens of feet on each side of the igneous rock is fractured and recrystallized. The altered limestone weathers to a brownish-gray rough spongy surface. In thin section it appears 
to be composed of calcite, pyrite, and abundant brown cloudy nonbirefringent material.

\section{STRUCTURE}

\section{FRESHWATER BAY SYNCLINE}

The Freshwater Bay syncline, named by Buddington and Chapin $(1929$, p. 315$)$, is the major structural feature of the mapped area. The plunge of the structure is southeastward less than $10^{\circ}$. The general dip of the limbs is approximately $45^{\circ}$. The trough of the syncline at Iyoukeen Cove comprises the youngest strata of the mapped area, the upper gypsiferous part of the Iyoukeen formation. The axis of the syncline is offset left-laterally by eastward-striking faults. The southwest flank is further complicated by a northwestward-striking fault system. The northeast flank has been locally complicated by thrusting from the northeast. Intrusion of the trough of the syncline by the Gypsum Creek quartz monzonite was apparently accompanied by minor marginal thrusting. Small remnants of folded Mississippian strata, now roof pendants within the intrusive body, appear to have been carried or pushed upward from their normal position deep in the trough of the syncline.

\section{FAULTS AND IINEAMENTS}

Within the Freshwater Bay area, faults have been identified and examined locally. Their exposure is generally poor in this heavily timbered and glaciated area, and their location and the nature of movement can generally be inferred only from the distribution of stratigraphic units. Many lineaments, some of which have been identified as faults in the field, are clearly expressed on aerial photographs. These lineaments are interpreted as probable surface expressions of faults or shear zones. They are commonly troughlike depressions a few tens of feet wide to which drainage has adapted itself. Running water and other agents of erosion have further accentuated these zones by removal of rock that has been crushed by faulting. The faults shown on the geologic map (pl. 1) have been divided into two groups: (1) Faults based on field evidence; (2) faults based on photointerpretation. The location of the second group was derived from linear features expressed on aerial photographs. Faults and lineaments may be summarized and generally described in the following sets: (1) Eastward-striking faults and associated lineaments; (2) northwestward-striking faults and associated lineaments; (3) northwestward-striking thrust faults; and (4) marginal thrust faults near intrusive bodies. 


\section{FASTWARD-STRIKING FAULTS AND ASSOCIATED LINEAMENTS}

Eastward-striking left-lateral faults and associated lineaments are prominent only in that area bounded by Freshwater Bay on the south, the North Shore fault on the west, and the valley of Iyouktug Creek on the northeast. Within this area, the eastward-striking fault set has offset all exposed strata between and including the Kennel Creek limestone and the Iyoukeen formation subsequent to their folding. This set is not observed to cut the quartz monzonite intrusive body but is present both east and west of the Gypsum Creek quartz monzonite body. The most prominent of the set is the Iyouktug fault whose apparent horizontal displacement is approximately 1 mile, with the north block moved westward. Minor faults both north and south of the Iyouktug fault show either an apparent vertical displacement downward with the north block or an apparent left-lateral horizontal displacement.

\section{NORTHWESTWARD-BTRIKING FAULTS AND ABSOCIATED LINEAMENTS}

Northwestward-striking faults and associated lineaments form a wide zone along both the north and south shores of Freshwater Bay on the west limb of Freshwater Bay syncline. This fault system offsets all strata exposed in the Freshwater Bay area. No lineaments can be traced across the Gypsum Creek quartz monzonite other than what appears on aerial photographs to be a joint set not mapped but roughly parallel to and possibly related to northwestward-striking faults. Northward-trending lineaments, vaguely to well expressed on aerial photographs northwest of the head of Freshwater Bay, may represent splits and joins within this system, but their nature has not been ascertained by field observation. Similarly the significance of several northward-trending lineaments across the granite body west of Freshwater Bay has not been evaluated. On the west side of the syncline, a strongly expressed northwestward-striking system of faults appears to truncate all faults of the eastward-striking system. West of Freshwater Bay the northwestward-striking faults appear to be dominantly right lateral.

The North Shore fault has an apparent vertical displacement downward on the west side, and cuts strata of the Freshwater Bay and Iyoukeen formations on the west limb of the syncline. A complicated zone of parallel faults, splits, and joins borders the North Shore fault on the west. Block faulting is indicated (cross section $C-C^{\prime}$ of pl. 1) with, locally at least, some right-lateral horizontal displacement.

The Peninsula fault shows an apparent vertical displacement downward on the north side bringing volcanic rock of the Freshwater Bay formation against all members of the Iyoukeen formation. Its rela- 
tions to the North Shore fault zone and to the eastward-striking leftlateral faults are not known. Depth of water close to the southern shore of Iyoukeen Peninsula indicates the probability that the fault extends along the peninsula and just offshore.

The North Fork fault has thrown Kennel Creek limestone against the volcanic rock of the Freshwater Bay formation. Distribution of mapped units indicates either right-lateral displacement, vertical displacement with the east side downthrown, or a combination of the two wth a horizontal component of displacement of approximately 1 mile. The Kennel Creek fault shows movement similar to the North Fork fault, with strata of the Cedar Cove formation against Kennel Creek limestone along strike but with slightly less horizontal displacement indicated. Neither fault has been carefully studied in the field.

The South Shore fault shows the greatest apparent horizontal displacement of the faults in the northwestward-striking system. Rightlateral displacement, vertical displacement with east side downthrown, or a combination of the two is proposed to explain nearly $2 \frac{1}{2}$ miles of apparent horizontal displacement along the fault. Strata of the Kennel Creek, Cedar Cove, and Freshwater Bay formations are offset by the fault. The East Point fault may be an extension of the South Shore fault or may represent one of several splits from it. It is presumed to have a right-lateral component of movement in accord with what is known of the northwestward-striking system.

The Cedar Cove fault may represent the extension of the North Short fault, or a split from it, that has thrown Kennel Creek limestone against volcanic rock of the Freshwater Bay formation, which strikes into the limestone across the fault. Distribution of mapped units indicates movement similar to other faults of the system.

The False Bay fauit zone cannot be properly evaluated as to displacement and nature of movement with available data. Northwestward extension of the zone beneath Quaternary sediments is considered possible. The zone lies mainly within contorted and muchfractured argillite and graywacke, stratigraphically below the Kennel Creek limestone. At the north edge of the map area, steeply dipping clastic strata of the older argillite-graywacke unit have been thrown against gently dipping Kennel Creek limestone, possibly by a highangle reverse fault.

\section{NORTHWESTWARD-STRIKING THRUST FAULTS}

Thrust faulting, with formations having been overridden by thrust plates from the northeast, seems indicated by the absence of at least 7,500 feet of strata normally present in the composite stratigraphic sequence of the Freshwater Bay area. Near the mouth of Wukuklook 
Creek, Kennel Creek limestone abuts against the upper limestone member of the Iyoukeen formation. The missing strata include at least 7,500 feet of volcanic rock of the Freshwater Bay formation and the two lower members of the Iyoukeen formation. The suggested Wukuklook thrust zone appears to cross Sonyakay Ridge as a zone of parallel lineaments south of Iyouktug fault and may extend into the valley of Iyouktug Creek.

Thrusts along the west-northwestward-striking False Bay fault zone can neither be confirmed nor denied on the basis of present knowledge. However, the traces of the strongly expressed Iyouktug fault do not appear northeast of the valley of Iyouktug Creek. The thrusting probably postdated both the formation of the eastwardstriking fault set and the emplacement of the Gypsum Creek quartz monzonite. The thrust zone appears to truncate the strongly expressed eastward-striking faults. The quartz monzonite body is presumed to have provided a buttress effect during the thrusting that may represent the latest major tectonic activity.

\section{MARGINAI THRUST FAULTS NEAR INTRUSIVE BODIES}

Marginal thrust faults occur locally near the edges of the Gypsum Creek quartz monzonite. High-angle minor reverse faults separate thin plates of intricately drag-folded limestone near the sharply defined north contact between the headwaters of Wukuklook Creek and the eastern tributary of Seal Creek. Here also the upturning of the strata against the contact of the intrusive body probably indicates forceful intrusion. Marginal thrusts are suspected but not proved to the south and east of the quartz monzonite pluton.

\section{GEOLOGIC HISTORY}

In pre-Middle Devonian time, perhaps in the Silurian or Early Devonian, an apparently unfossiliferous sequence of interbedded muddy sands and muds, more than 5,000 feet thick accumulated in a subsiding trough or basin.

The muddy sands were deposited periodically by mud-choked currents, possibly in quiet water below wave base. 'The source must have been an area of high relief from which rapid erosion and transportation delivered an abundance of nearly unweathered and poorly sorted material to the site of deposition. Most likely the mud beds also were deposited in quiet water. Because they show no signs of current action, they probably settled from standing water between periodic episodes of sand deposition.

Near the end of the clastic deposition, coarse sand, gravel, and boulder beds were deposited along the southern border of the area. 
This probably reflected nearby uplift, which may have marked the beginning of a more widespread uplift resulting in the emergence and subsequent erosion of the Freshwater Bay area. In any case, clastic sedimentation ended after the deposition of these coarse clastics.

In the Middle Devonian, following uplift and possible erosion, a subsiding marine trough again occupied the Freshwater Bay area. The landmass that had supplied the clastic debris was by this time either reduced to low relief or completely submerged. In either case, carbonate deposition prevailed in the area. Continued subsidence allowed several thousand feet of limestone, the Kennel Creek limestone, to accumulate.

Near the close of the period of deposition of the Kennel Creek limestone, very thin layers of clay, possibly representing ash from distant volcanic eruptions, were deposited periodically.

The beginning of the deposition of the Cedar Cove formation was marked by an influx of clastic debris, probably due to uplift of a nearby volcanic terrain. Mud, sand, and gravel were interbedded with limestone in the early stages. Later, during the deposition of the upper part of the lower member of the Cedar Cove formation, only clastic sediment was deposited. About 1,500 feet of clastic sediment and limestone accumulated before the influx of clastic debris ceased. Cessation of uplift and the reduction of the source area to a region of low relief probably caused a termination of clastic deposition.

An episode of predominantly carbonate deposition followed during which more than 1,000 feet of limestone with a minor amount of dolomite and tuff (the upper member of the Cedar Cove formation) accumulated. Periodic volcanism, presumably in the source area, occurred during the deposition of the middle part of the upper member, but carbonate deposition remained dominant. Middle Devonian sedimentation apparently ended with uplift, emergence, and erosion in the Freshwater Bay area.

Following a period of erosion during which in places the entire Cedar Cove formation and a part of the upper Kennel Creek limestone may have been removed, an episode of volcanic activity began. In the Late Devonian more than 6,500 feet of highly variable volcanic rocks and associated sediment of the Freshwater Bay formation were deposited in a subsiding basin or trough that was, at least in part, marine. During the volcanism numerous dikes and sills, probably in part volcanic feeders, cut the underlying rocks. The Upper Devonian record ends with the cessation of volcanism, emergence of the land, and erosion.

In early Mississippian time, subsidence and encroachment of the sea resulted in renewed marine sedimentation. The predominant 
carbonate deposition indicates that the source areas were either of low relief or distant. After about 600 feet of limestone composing the lower limestone member of the Iyoukeen formation had accumulated, uplift in the source area, possibly to the east, produced a supply of clastic material. Mud was deposited in the southeastern two-thirds of the area, while carbonate was being deposited in the northwestern third.

By Late Mississippian time, the source area was reduced to a region of low relief and carbonate deposition was resumed. Subsidence of the sea floor allowed more than 3,000 feet of limestone, the upper limestone of the Iyoukeen formation, to be deposited. The record of preQuaternary sedimentation ends with the deposition of this limestone.

After the deposition of the Late Mississippian strata, stresses acting upon the area produced major southeastward-plunging folds. Later deformation developed an eastward-striking fault set displacing these major folds. During or after this deformation, the sedimentary strata were invaded by igneous material. Within this episode of intrusive activity, all the granitic and dioritic intrusive bodies may have been created. Emplacement of the Gypsum Creek quartz monzonite appears to have been accompanied by marginal thrusting. Subsequent deformation developed a northwestward-striking system of right-lateral faults truncating the eastward-striking set. Thrust faulting from the northeast is postulated as the final major recordable tectonic event in the area.

In summary, the suggested sequence is:

1. The development of an enstward-striking fault set, displacing folded Mississippian and older formations.

2. Marginal thrusting during emplacement of the Gypsum Creek quartz monzonite.

3. The development of a northwestward-striking fault system, truncating the eastward-striking fault set.

4. Thrust faulting from the northeast, covering the eastward extensions of eastward-striking faults and riding over a considerable thickness of Devonian rocks.

Although uplift, which probably accompanied this episode of deformation, undoubtedly initiated a cycle of erosion, present-day topography may be the result of a later cycle of uplift and erosion. In the Quaternary, glaciers reshaped terrain and deposited glacial gravels, sand, and silts in the valleys and lowlands.

Today, with the glaciers gone, streams are modifying the landscape - cutting away the hills, filling in the valleys, and building deltas at their mouths. 


\section{LITERATURE CITED}

Bowsher, A. L., Dutro, J. T., Jr., and Patton, W. W., Jr., 1957, Exploration of Naval Petroleum Reserve No. 4 and adjacent areas, northern Alaska, 1944-53, pt. 3 : U.S. Geol. Survey Prof. Paper 303-A and B, 45 p.

Brooks, A. H., and others, 1906, Progress of investigations of mineral resources of Alaska in 1905 : U.S. Geol. Survey Bull. 284, 169 p.

- 1907, Progress of investigations in mineral resources of Alaska in 1906: U.S. Geol. Survey Bull. 314, 235 p.

- 1908, Progress of investigations in mineral resources of Alaska in 1907: U.S. Geol. Survey Bull. 345, 294 p.

Buddington, A. F., and Chapin, Theodore, 1929, Geology and mineral deposits of southeastern Alaska: U.S. Geol. Survey Bull. 800, 398 p.

Correns, C. W., 1950, Zur Geochemie der Diagenese, I Das Verhalten von $\mathrm{CaCO}_{3}$ und $\mathrm{SiO}_{2}$ : Geochim. Cosmochim. Acta. v. 1, p. 49-54.

Emmons, R. C., and Gates, R. M., 1948, The use of Becke line colors in refractive index determination: Am. Mineralogist, v. 33, nos. 9-10, p. 612-618.

Flint, G. M., Jr., and Cobb, E. H., 1953, Gypsum deposits near Iyoukeen Cove, Chichagof Island, southeastern Alaska: U.S. Geol. Survey Bull. 989-B, 37 p.

Kindle, E. M., 1907, Notes on the Paleozoic faunas and stratigraphy of southeastern Alaska: Jour. Geology, v. 15, no. 4, 314-337.

Kirk, Edwin, 1918, Paleozoic glaciation in southeastern Alaska : Am. Jour. Sci., 4th ser., v. 46, no. 273, p. 511-515.

1927a, Pycnodesma, a new molluscan genus from the Silurian of Alaska: Natl. Mus. Proc., v. 71, art. 20, p. 1-9.

1927b, Pycinodesma, new name for Pycnodesma Kirk not Schrammen: Washington Acad. Sci. Jour., v. 17, no. 21, p. 543.

Knopf, Adolph, 1912, The Sitka mining district, Alaska: U.S. Geol. Survey Bull. $504,32 \mathrm{p}$.

Krynine, P. D., 1948, The microscopic study and field classifleation of sedimentary rocks: Jour. Geology, v. 56, no. 2, p. 130-165.

Kuenen, Ph. H., 1953, Significant features of graded bedding: Am. Assoc. Petroleum Geologists Bull., v. 37, no. 5, p. 1044-1066.

1957 , Sole markings of graded graywacke beds: Jour. Geology, v. 65, no. 3, p. 231-258.

Mansfleld, G. R., 1927, Geography, geology, and mineral resources of part of southeastern Idaho: U.S. Geol. Survey Prof. Paper 152, 453 p.

Nolan, T. B., 1935, The Gold Hill mining district: U.S. Geol. Survey Prof. Paper $177,172 \mathrm{p}$.

Pettijohn, F. J., 1957, Sedimentary rocks: New York, Harpers and Bros., 718 p.

Rodgers, John, 1940, Distinction between calcite and dolomite on polished surfaces: Am. Jour. Sci., v. 238, p. 788-798.

Smith, P. S., 1932, Mineral resources of Alaska in 1929 : U.S. Geol. Survey Bull. $824,109 \mathrm{p}$.

Wentworth, C. K., 1922, A scale of grade and class terms for clastic sediments: Jour. Geology, v. 30, p. 377-392.

Wentworth, C. K., and Williams, Howel, 1932, The classification and terminology of the pyroclastic rocks : Natl. Research Council Bull. 89, p. 19-53.

Williams, Howel, Turner, F. J., and Gilbert, C. M., 1954, Petrography, an introduction to the study of rocks in thin sections: San Francisco, W. H. Freeman and Co., $406 \mathrm{p}$. 



\section{INDEX}

Page

Age and correlation

Ceda Cover formation

Freshwater Bay formation

Iyoukeen formation.

Kennel Creek limestone.

Silurian or Devonian rocks

Alspah limestone.

Alexander Archipelago.

Andesite dikes and sills.

Andesitic member, upper, Freshwater Bay formation.

Angoon, Admiralty Island.

Argillite and graywacke unit

Argillite and graywacke...............................

Argillite sequence............................. 10,11

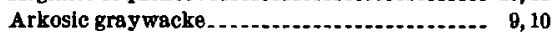

Banff formation............................... 37

Bedded rocks........................... 6-37

Bibliography.................................... 51

Boat Harbor . .......................... 13

Brazer formation................................. 37

Cedar Cove............................ 14, 17, 23, 25

Cedar Cove fault

Cedar Cove formation. $5,13,14,15,17-23,31,33,47,49$ age and correlation......................... 22-23

distribution and topographic expression . 17-18 stratigraphy and petrography............ 18-22

Cedar Island ................................ 17, 27, 28

Chatham Strait............................... 3, 7,14

Climate of Fresh water Bay ................... 3

Conglomerate at East Point..................... 12-13

Contact metamorphism.................... 40,41,43

Devonian or Silurian rocks.................. 6-13

Devonian rocks. ............................... 13-32

Dikes and sills.................................. 43-45 andesite dikes and sills. ................... 43-44 spessartite lamprophyre.................... 44-45

Distribution and topographic expression...... 6-8,

Cedar Cove formation $\quad 13,17,23,32$

Freshwater Bay formation................ 23

Iyoukeen formation - .

Kennel Creek limestone..................... 13-14

Silurian or Devonian rocks.............. $6-8$

East Point.

$3,12,13,14,17,18,24$

East Point fault

False Bay area $\ldots \ldots \ldots \ldots$
False Bay $\ldots \ldots \ldots \ldots$

False Bay............................. $6,7,8,8,10,13$ fault zone. ........................... 47, 48
Fsults and linesments........................ C45-48

Frults, eastward striking and associated linea-

ments. ........................... 46

marginal thrust, near intrusive bodies .... 48

northwestward striking.................... 47

northwestward striking and associated lineaments. ....................... 46

Fossils_..................... 13, 15, 16, 17, 22, 32, 36, 37

Freshwater Bay formation................... 17, $18,23-32,37,42,43,46,47,48,49$

age and correlation ..................... 31-32

distribution and topographic expression .. 23

lower greenstone member................. 24-25

middle rhyolitic member.................... 25-28

northeast limb of Freshwater Bay syn. cline

southwest limb of Freshwater Bay syn. cline................................ 24-29

stratigraphy and petrography ........... 23-31

upper andesitic member..................... 28-28

volcanism

Freshwater Bay syncline...................... 5 ,

$6,13,23,24,29,30,32,33,34,36,38,45,46$

northeast limb........................... 20-31

southwest limb............................ 24-28

Freshwater Creek. ...................... 3, 17, 25, 27

Geologic history ............................. 48-50

Gold Hill district, Utah........................ 17

Graywacke, arkosic......................... $\quad 0,10$

high rank................................ 10,20

Greenstone, the term ........................ 25

Gypsum Creek..................... 5, 32, 34, 38, 39, 40

Gypsum Creek pluton................... 40

Gypsum Creek quartz monzonite............ 32

$34,38-40,45,46,48,50$

distribution and location................... 38

petrography................................. 30-40

contact metamorphism .................... 40

Gypsum deposits............................... 34-36

High-rank graywacke......................... 10, 20

Introduction . ................................. 2-4

Intrusive igneous rocks. . .......................... 37-45

Iyoukeen Cove...................... 4, 5, 18,32,34,46

Iyoukeen formation.......................... 23, 24, 30 ,

$31,32-37,38,39,42,43,44,45,46,48,60$

age and correlation . ................... 36-37

distribution and topographic expression .. 32

gypsum deposits....................... 34-36

stratigraphy and petrogrephy . ............ 32-34

Iyoukeen Peninsula Iyouktug Creek.................. 3, 8, 10, 18, 43, 46, 48

Iyouktug fault ............................... 46, 48 
Page

Kayak shalo

Kennel Creek. .......... 3, 5, 7, $12,13,14,15,17,18,10,21-22,24,40,41$

Kennel Creek rault tone $\ldots \ldots, 8,11,12,13-17$,

Kennel Creek limestone _...... 5, 8, 11, 12,13-17, age and correlation. . . . distribution and topographic expression . - 13-14 stratigraphy ........... 14-16 Kennel Creek pluton

Lodgepole limestone.......................... 37 Lower greenstone member, Freshwater Bsy formation . . . 24-25

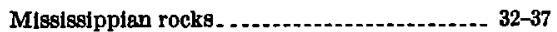

North Shore fault

46,47

Northeest limb of Freshwater Bay syncline_ _ 20-31

Paleozole tllite

Pavlof Harbor

Pavlof River

3,7

Pluton at the head of Kennel Creek. ......- 40-42

Pluton, contact metamorphism.............- 41-42

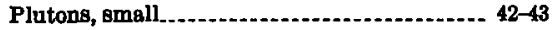

Porphyritic andesite. ..................... 30

Port Frederick ............................ 7, 23,31, 32

Preclpitation of Freshwater Bay _....... 3

Previous investlgations of ares.............. 4-5

Purpose and scope.

Qusternary deposits.......................... 37

Redcliff Islands

Rhyolitic member, middle, Freshwater Bay formation

Rundle formation
St. James Bay . . . . . .

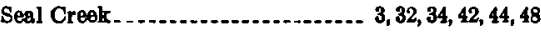

Sllurian or Devonian argillite and graywacke sequence...................... 13,14

Sllurian or Devonian rocks. .

Sitka D-3 quedranglo. .................. 2,

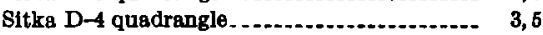

Sitka spruce................ 4

Small plutons. ....... $42-43$

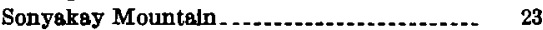

Sonyakay Ridge. ..................... 14, 48

South Fork of Freshwater Creek . .........., 3,11

South Bhore fault . . .

Southwest limb of Freshwater Bay syncline. . 24-29

Southwest of Freshwater Bay . ............. 11-12

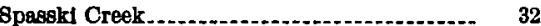

Spessartite lamprophyre............... $44-45$

Stephen R. Capps, motor vessel........ 6

Stratigraphy and petrography........ 8, 18, 23, 32

Cedar Cove formation.................. 18-22

Freshwater Bay formation. . .

Iyoukeen formation . . . . . . . . . .

Sllurian or Devontan rocks............... 8-13

Stratigraphy. . ......... 14-16

Structure............. $45-48$

Temperature of area.......................... 4

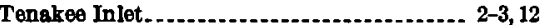

Thin sections of rock types. 6

Unnemed argllite and graywacke. .......... 6-13

Wachsmuth limestone _. . . .

Wachusett Cove.................... 24, 25

Wentworth grain size scale

Western hemlock............................ 4

Wuknklook Creek . . ....... 23, 24, 20, 30, 33, 34, 47-48

Wukuklook thrust zone....................... 48 




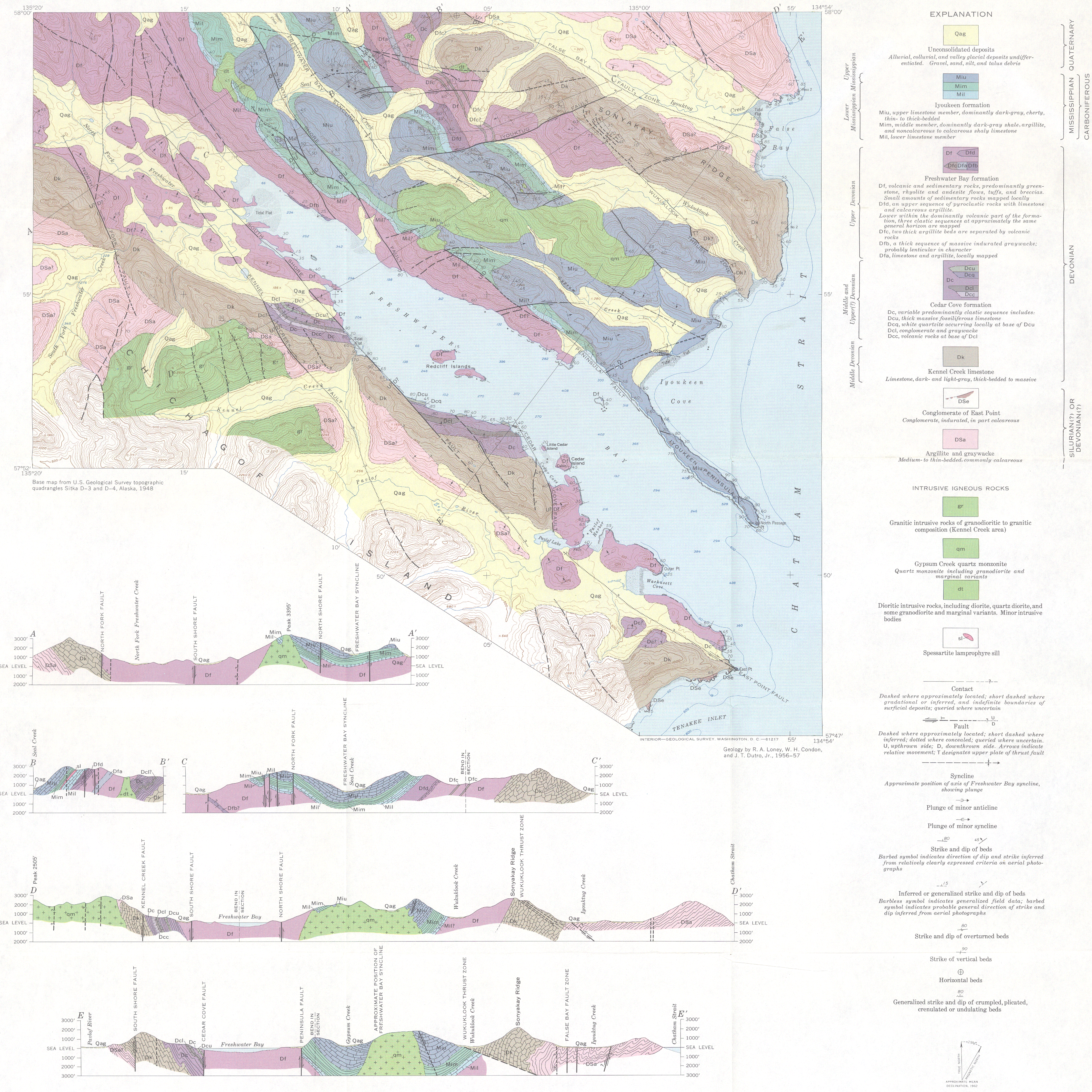



UNITED STATES DEPARTMENT OF THE INTERIOR GEOLOGICAL SURVEY

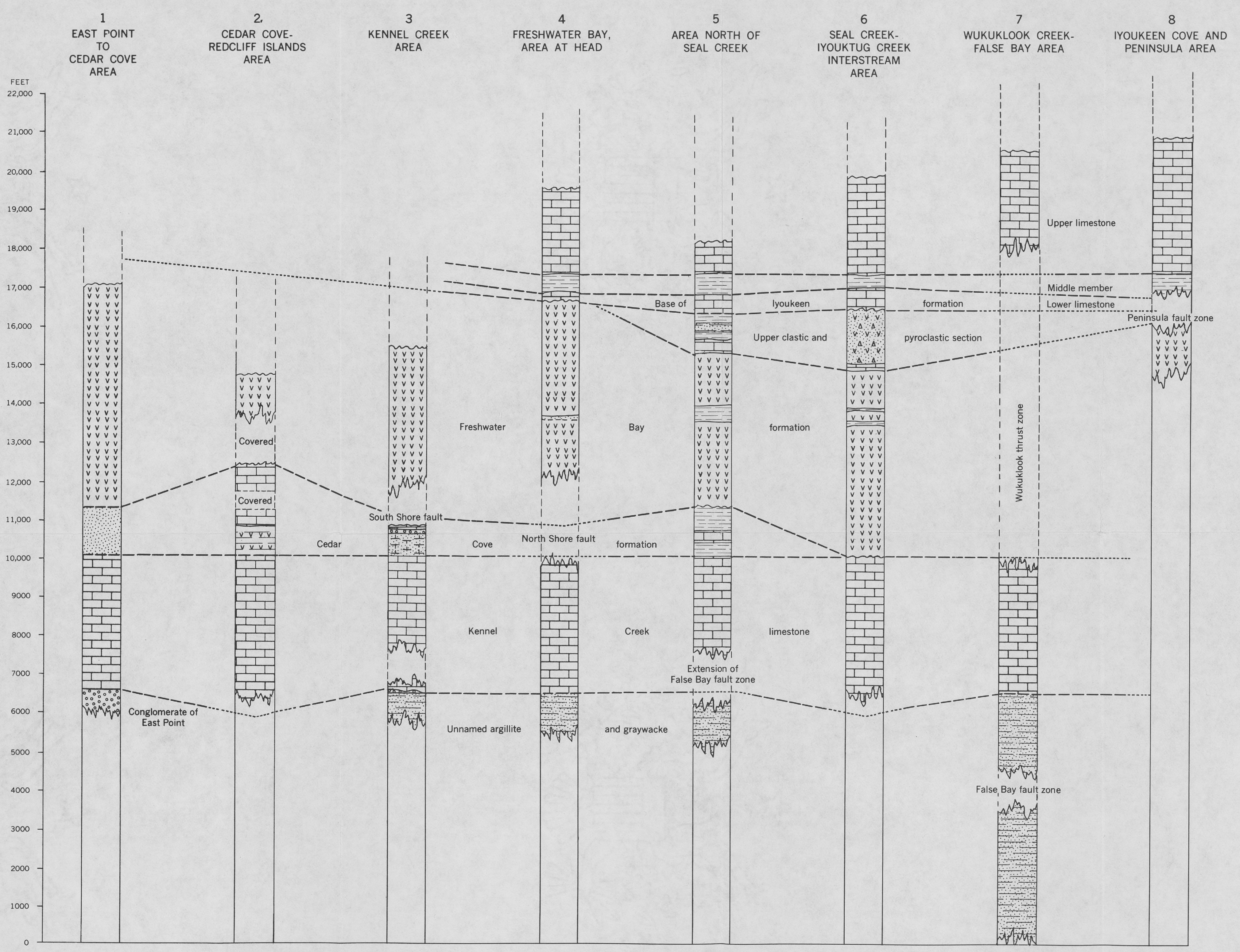

EXPLANATION

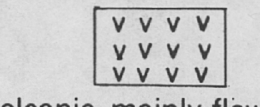

Volcanic, mainly flow rocks

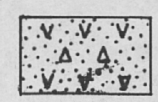

Volcanic, mainly pyroclastic rocks

Clastic rocks, mainly graywacke

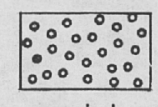

Clastic rocks, mainly conglomerate

Fine-grained rocks, mainly argillite

$\longrightarrow$

Interbedded argillite and graywacke

Y.y.

Clastic rocks, interbedded with
volcanic rock, limestone, and

年

Limeston

These sections have been compiled using
apparent thicknesses of stratigraphic Units and structural sections as graphidetailed stratigraphic sections, generalized within individual areas, reading
clockwise and consecutively around the
Freshwater Bay area from East Point 
